\title{
14
}

\section{Trade reform, macroeconomic policy and sectoral labour movement}

\author{
Jennifer Chang and Rod Tyers
}

Although the Chinese economy continues to grow rapidly, since the late 1990 s there has been evidence of a slow down in per capita rural income growth. One explanation for this is that the relocation of labour from agriculture to manufacturing and services, essential in any growing developing economy, has been retarded. This could be due to policy disincentives designed to control urban congestion, such as the household registration or hukou system (lanchovichina and Martin 2002) or information asymmetries and transaction/infrastructural costs (Sicular and Zhao 2002). An alternative explanation is that comparatively poor performance in China's rural sector is due to economic reforms, and in particular to trade reform commitments made in the lead-up to the WTO accession (Anderson et al. 2002).

It is the central hypothesis of this chapter that this comparative decline in rural performance is due, at least in part, to a combination of China's adherence to a de facto fixed exchange rate regime and shocks that have tended to depreciate its real exchange rate. Most significant among these shocks was the surge of (largely illegal) outflows on the capital account and the associated private investment slowdown during the Asian financial crisis (Yang and Tyers 2001). Since then, however, numerous trade reforms have been implemented, all of which have tended to encourage Chinese consumption to shift towards foreign goods, thus reducing the price of home goods relative to pre-tariff prices of foreign goods and hence further depreciating the real exchange rate (Rees and Tyers 2002). 
By definition, a real depreciation must be accompanied either by a nominal depreciation, a domestic deflation, or a combination of both. The de facto peg to the US dollar has therefore necessitated China's deflation. When prices are falling there is downward pressure on wages. Even if wages fall only slightly more slowly than prices, however, other things being equal, employment growth in the wage sectors of the economy can be expected to decline. ${ }^{1}$ In the Chinese case this appears as high real wage growth but reduced labour demand growth in the modern sector and hence a 'bottling up' of workers in the rural sector and reduced rural income per capita.

This chapter examines the relevance of this story to China's comparatively poor recent per capita rural income growth performance using short and long-run comparative static analysis. The shocks considered are China's WTO accession commitments and the model used is a development of that introduced by Yang and Tyers (2000) and applied more recently by Rees and Tyers (2002). It is a multisector, multi-country comparative static macro model, the microeconomic components of which have their origins in GTAP. ${ }^{2}$ As in the application by Rees and Tyers, all countries have open capital accounts and forward-looking investor behaviour is represented in the short run via expectations formed from long-run simulations. The focus here, however, is on labour relocation and the short-run consequences of trade reform shocks for the uptake of labour in the manufacturing and services sectors. ${ }^{3}$ We examine the pace of such labour relocation historically and compare this with simulated changes in labour demand following WTO accession.

We observe a reversal in the rate of relocation of workers from agriculture to manufacturing after 1998 and a glut of workers in the rural sector (Dolven 2003). Our simulations confirm that the relocation slowdown has been been enhanced by China's broader macroeconomic policy regime. Indeed, the exchange rate regime, combined with capital controls, appears to have restricted the flow of workers into manufacturing and services by at least a full one per cent per year and into services by at least two per cent per year.

\section{Urban-rural inequality and worker relocation}

The pace of rural per capita income growth depends on the rate at which surplus labour is generated by agricultural change and the corresponding rate at which surplus workers in agriculture are absorbed into the manufacturing and services sectors. It is a common view that the economic reform of the early 1980 s, which brought de- 
collectivisation and the household responsibility system, along with associated increases in agricultural labour productivity, created a substantial rural labour surplus. ${ }^{4}$ Moreover, prior to that reform, wages were not market determined and there is evidence of considerable underemployment. This was due, in part, to the seasonal nature of agricultural activity, which meant that many workers were left idle in the off-peak parts of the agricultural cycle and yet were unable to take employment elsewhere (Banister and Taylor 1989).

An exacerbating factor on the supply side was rapid rural population growth in the pre-reform period. Even though rural population growth slowed in the 1970 s and 1980 s, the rural labour supply continued to grow strongly in the aftermath of the 'baby boom' periods of the 1950 s and 1960 s. $^{5}$ On the demand side, China's prereform economic strategy promoted relatively capital-intensive heavy industries. These two effects tended to raise underemployment in the rural sector, where, although rural communes were disbanded, all workers were still technically employed. ${ }^{6}$ The post-reform period therefore carried considerable potential for worker relocation from agriculture into other sectors. The subsequent volume of internal migration would depend, then, on economic incentives in the form of urban-rural income inequality and on both policy-induced and natural barriers to migration.

\section{Urban-rural inequality}

There is income inequality in China between urban and rural residents as well as within both urban and rural areas. Inequality also has a strong regional pattern, particularly between inland and coastal provinces. Of overall income inequality, Lozada (2002) estimates that 75-80 per cent is due to the urban-rural divide. Official estimates of the trends of rural and urban household incomes indicate a general upward trend in income for both areas while urban income has experienced comparatively sharp increases in the 1990s (Figure 14.1). The corresponding proportional difference between urban and rural household income is plotted in Figure 14.2. In the early 1980s, rural incomes grew relatively rapidly and there was a decline in urban-rural inequality. Since then, however, urban incomes have grown much more rapidly, most prominently since the early to mid $1990 \mathrm{~s}^{7}$

\section{Internal migration}

Were there no costs or barriers to internal migration, workers would be expected to respond to the widening income gap between rural and urban areas by migrating 
until wages were much closer. Although the estimated number of internal migrants has grown (by 100 million since the 1980s) these relocations have been insufficient to stem the growing inequality (Dolven 2003). Some of this apparent growth in inequality is due to a rise in skilled employment in urban areas, while some is due to reduced urban labour demand associated with real wage growth and to official migration barriers. Together, these factors appear to have left an expanding labour supply 'bottled up' in the rural sector. The key official barrier has been the Household Registration System (HRS).

Introduced in major cities in 1951 and extended to rural areas in 1955, the HRS was intended to deal with the escalating urban influxes of rural migrants at the time of the Great Famine of 1959-61 (Chan and Zhang 1999). The associated food shortages continued into the 1970s, only ending in the 1980s (Zhao 2000). The HRS

Figure 14.1 Per capita annual income of urban and rural households (yuan)

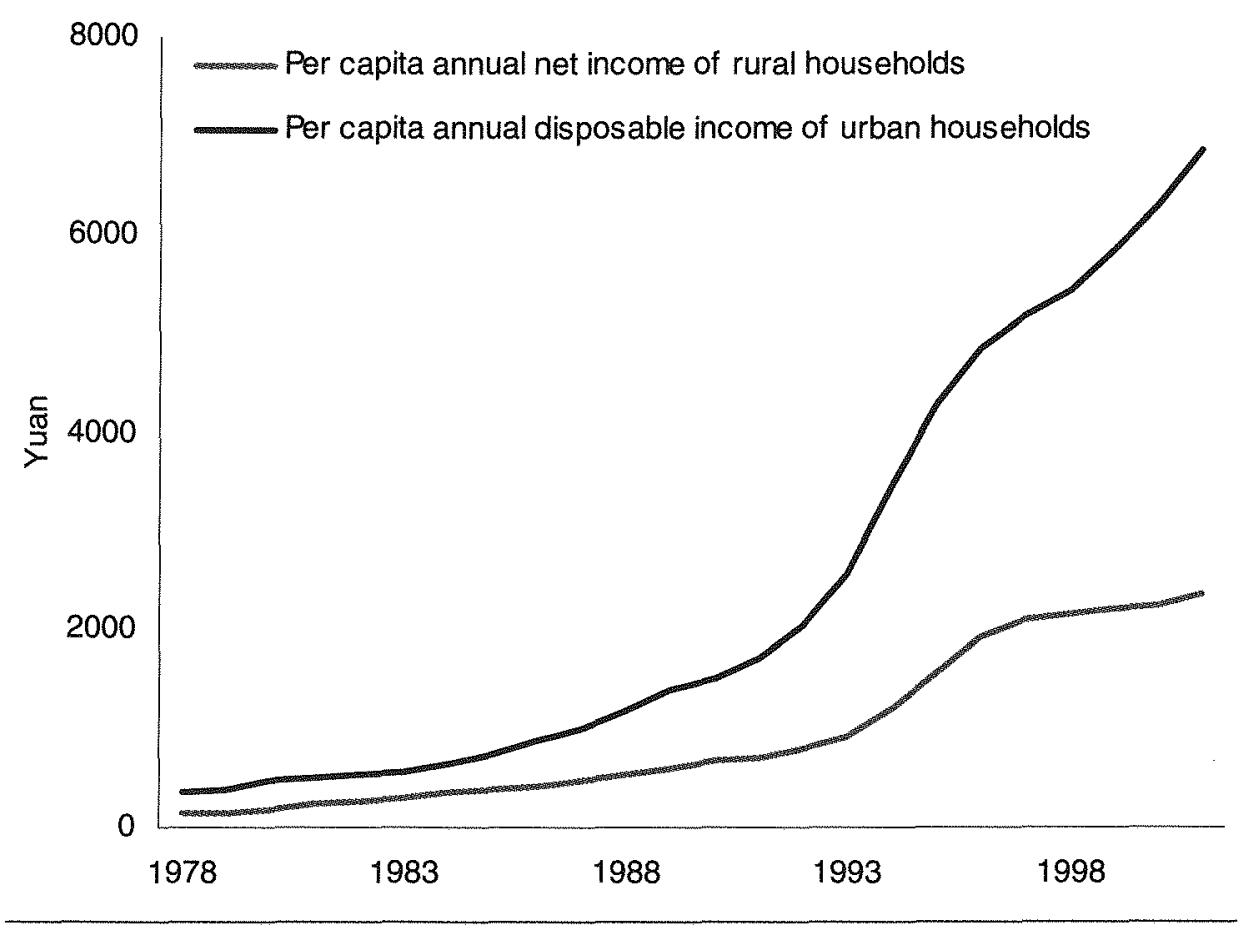

Source: National Bureau of Statistics, 2002. China Statistical Yearbook, 2002, China Statistics Press, Beijing. 
requires all citizens to register in their place of regular residence, often their birthplace. Moving from rural to urban areas requires a complex and costly application for a transfer to a local hukou. Prior to the reform in the 1980s this was a huge barrier, as without a proper hukou one would not qualify for government job assignment. Workers who ignored this requirement were denied social security benefits such as housing and other necessities, even food.

Decollectivisation in rural areas allowed income inequality to soften a little and non-farm rural industries to develop. This, and the household responsibility system that accompanied it, led to increased productivity in the agricultural sector. Thus, while rural incomes grew, so too did the proportion of workers considered redundant. ${ }^{8}$ The government began rewarding collective farms and cooperatives for production rather than quantified labour, so excess workers could be free to look for other jobs (Seeborg et al. 2000). The marketisation of food also meant that migrants were no longer restrained entirely by the need to obtain a local hukou to survive. Combined with the development of special economic zones and the increase in urban private and informal sectors, these conditions put the cities on a path of rapid development with growing demand for labour. Yet the HRS created ambiguous incentives for migrants. On the one hand it constrained people with access to land from migrating, since each was now responsible for his or her own land, which most saw as a form of social security (Chan 2000). On the other hand, individuals who had little or no access to land or who had specialised in what were to become low productivity rural activities were now less constrained.

Throughout the 1980s and 1990s, the HRS was gradually weakened by policy reforms and less stringent enforcement. Previously prohibited 'spontaneous' migration to jobs in urban centres was tacitly facilitated and tolerated, conditionally opening urban residency to rural workers and relaxing some of the strict controls. There has therefore been an increase in temporary urban migrants-workers going to cities and towns without official residential status, known as the 'floating population'. From the late 1980s onwards, transients made up over one-fifth of the population of such major cities as Beijing, Shanghai, and Guangzhou (Immigration and Refugee Board, Canada 2002). Many official restrictions remained, however, including the link between hukou status and welfare eligibility, the denial of education for migrant children and state job availability. In 1995, to re-assert control over internal migration, Zhao (2000) notes that tighter controls were imposed over the legality of urban residency and housing subsidies. ${ }^{9}$ 
As part of China's urbanisation strategy for the Tenth Five-Year Plan, Central Party Document No.11 of November 2000 allows a person and his or her immediate family to obtain urban hukous if he or she has fixed accommodation, stable work (in a job for more than one year) in the urban area. Urban hukou was also offered to those who would purchase a local commercial housing unit (to attract outside investment) and to holders of graduate degrees (attracting professionals). The focus of these reforms was still mainly small urban towns and small cities. Nonetheless, according to China's Committee to Restructure the Economy (SCORES), during 2001 about 600,000 rural residents acquired urban hukou in these small urban centres. More recently still, a State Council directive indicated that rural migrants have a legal right to work in cities. This directive prohibits job discrimination based on residency and orders that urban residency documents are to be provided to any

Figure 14.2 Gap between urban and rural incomes, 1978-2001 (per cent)

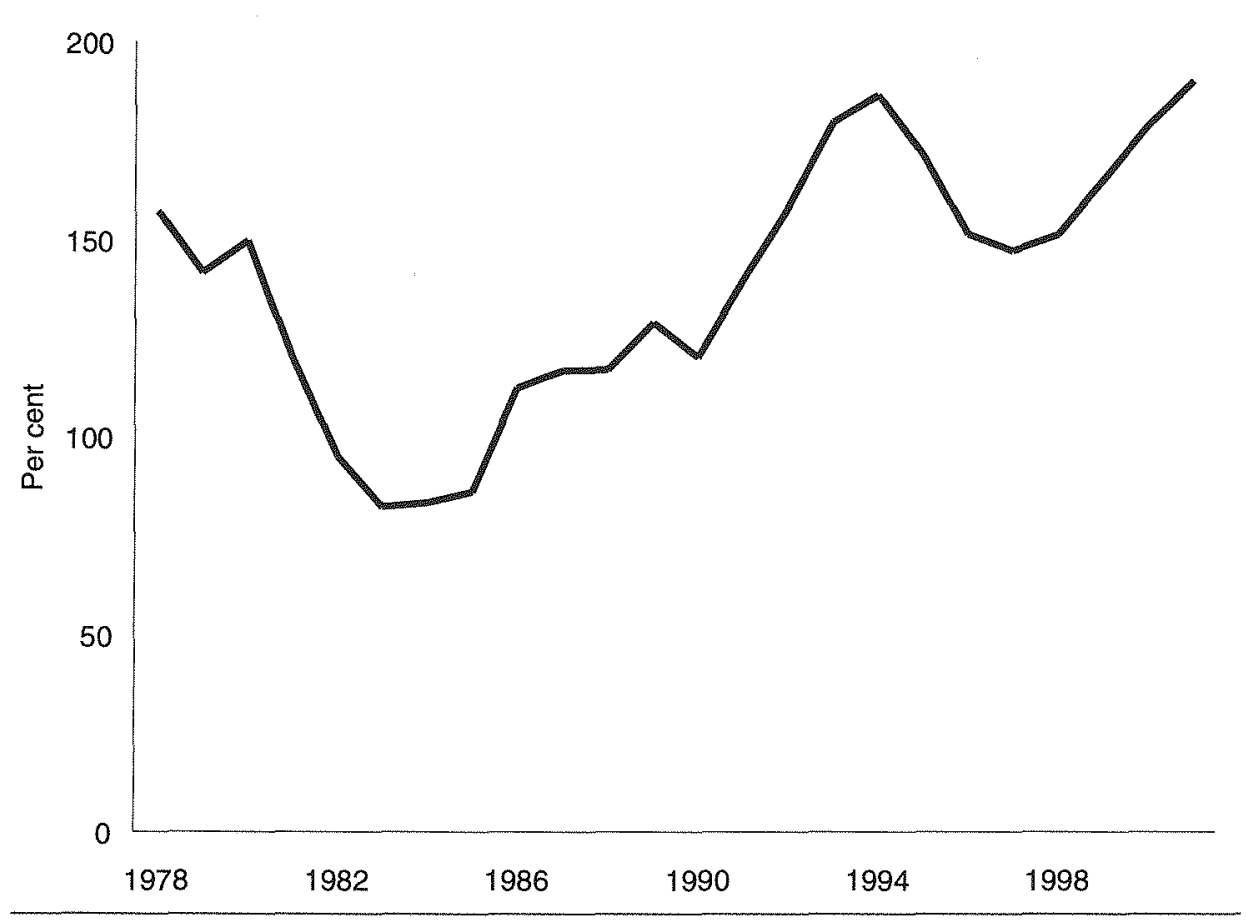

Source: Source: National Bureau of Statistics, 2002. China Statistical Yearbook, 2002, China Statistics Press, Beijing. 
workers who find employment. A further recent directive indicates that businesses should stop delaying wage payments to workers. This is a significant improvement for migrant workers as they often find that they are taken advantage of due to their uncertain legal status.

Official barriers to migration therefore appear to have had an ever diminishing effect in China, and least effect in the period since the Asian crisis of 1997. Other things being equal, then, we would expect an acceleration in the relocation of workers into jobs in the modern sector in that period. However, the evidence does not suggest that this has happened.

\section{Sectoral relocation of workers}

The early 1990s was a period of rapid industrial expansion during which workers relocated from the rural sector to the industrial and services sectors (Figure 14.3). Significantly, while the expected long-term rise in the share of services in total employment is borne out, industrial employment fell substantially during the Asian crisis period and failed to expand thereafter. Indeed, the farming and forestry sector shows annual declines in employment that peaked in 1993 and continued until 1996. In this period the Chinese economy grew at its highest rate ever. During the Asian crisis and in the period thereafter, however, relative declines in the growth rates of activity in manufacturing and services appear to have driven workers back to the rural sector. This back-flow appears to have continued in the post-crisis period.

\section{AGGREGATE PERFORMANCE SINCE THE ASIAN CRISIS}

In 1995, good weather and improved farming incentives brought a resurgence of the rural economy and the reform of state-owned industrial enterprises (SOES) was accelerated, precipitating substantial lay-offs (Meng 1998). These changed saving incentives, leading to a sudden increase in the private saving rate (Yang and Tyers 2000, 2001). The contractionary effects of these internal shocks were then worsened by the East Asian financial crisis, which saw the mostly illegal flight of a substantial part of China's additional private savings from the country, leading to a fall in private investment. At the same time, slowdowns and currency depreciations in other Asian economies made their exports relatively competitive, so that the dollar value of China's exports grew more slowly than in 1990-96 (Yang 1998).

Our macroeconomic policy story begins with the crisis and China's reaction to it. The shocks of that period-the rise in the domestic saving rate, the increased 
outflow on the capital account and the adverse change in the terms of tradedepreciated the real exchange rate. This can be seen from the following definition of the real bilateral exchange rate, for region $i$ with region $j$, as the common currency ratio of the price of a basket of region is goods and the price of a corresponding basket of region is goods:

$$
e_{i j}^{R}=E_{i j}\left(\frac{P_{i}^{Y}}{P_{j}^{Y}}\right)=\frac{P_{i}^{Y}}{\left(\frac{P_{j}^{Y}}{E_{i j}}\right)}
$$

where $E_{i j}$ is is nominal exchange rate with $j$, measured as foreign currency units per local unit, and the price index used is the GDP price, $P^{Y} .{ }^{10}$ This depreciates when the price of the basket of home goods falls relative to the corresponding basket of

Figure 14.3 Employment by industry group, 1990-2001 (million workers)

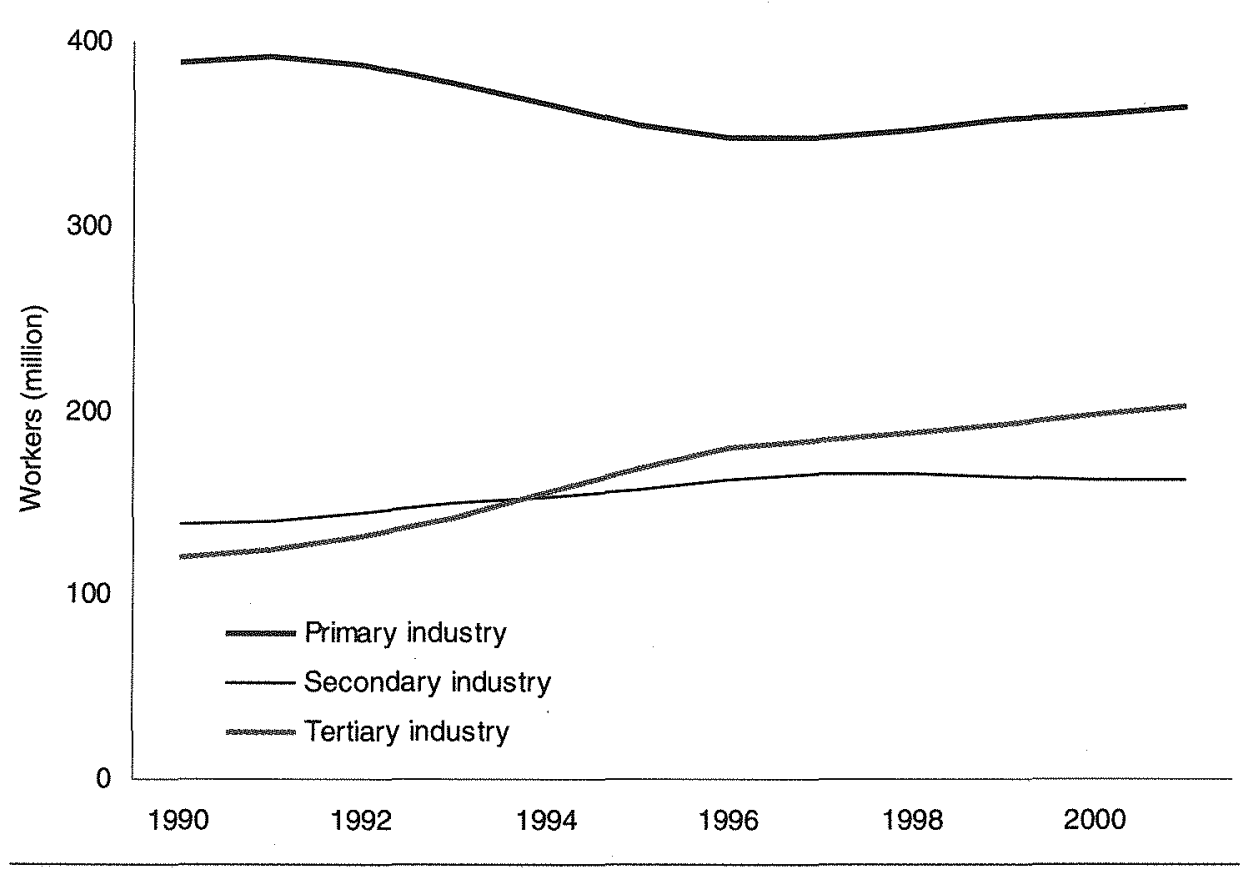

Source: National Statistical Bureau, 2002. China Statistical Yearbook (2002), China Statistics Press, Beijing. Primary industry: farming, forestry, animal husbandry and fishery. Secondary industry: mining, manufacturing, electricity, water, gas, construction. Tertiary: all other industries. 
foreign goods. The real depreciation during the crisis period, combined with the fixed nominal exchange rate, necessitated a monetary policy sufficiently restrictive to bring about a decline in the home price level relative to that in the United Statesa deflation. This was the first in a series of deflations in the crisis and post-crisis periods.

Shocks that cause real depreciations also include other elements of China's domestic reforms. By raising productivity, these factors reduce domestic costs relative to foreign costs and hence tend to reduce relative domestic prices. Similarly, trade reforms divert domestic demand away from home-produced goods towards imports and so they also tend to reduce the prices of domestic goods relative to the import prices of foreign goods. In the period 1997-2001, China embarked on substantial trade liberalisations, including the introduction of a duty drawback system on the imported inputs of export firms (Rees and Tyers 2002). Real depreciations due to such shocks would have occurred irrespective of China's exchange rate regime. But it is that regime which distributes the nominal effects of the real depreciations between falls in the home price level, or deflations, on the one hand and depreciations of the nominal exchange rate on the other.

The declines in China's prices indicate that, other things being equal, such deflations are contractionary (Table 14.1). ${ }^{11}$ This is because, even in the most flexible of industries, wage rates are renegotiated more rarely than product prices are adjusted. Lags in wage adjustment mean that deflation applies a profit squeeze that retards both employment growth and investment in the private sector. Consequently, real wage growth in China's modern sector has been extraordinarily high since 1996, (Figure 14.5) suggesting some deterrence of labour demand and overall growth in this sector. Weaker overall performance of the Chinese economy is indicated by its official GDP growth rates (Figure 14.4). These bottomed out in the crisis period at between seven and eight per cent per year, but have not recovered since.

Since 2001 China has embarked on a still more dramatic set of trade reforms as part of its WTO accession commitments. By themselves, these reforms will cause further real depreciations. Should there be no change in macroeconomic policy, growth and the relocation of workers into China's modern sector will continue to be retarded by deflation. In the remainder of the chapter we investigate the relationship between growth, labour relocation and macroeconomic policies in the aftermath of the WTO accession reforms. 
Figure 14.4 Official growth rate of real GDP, 1990-2001 (per cent)

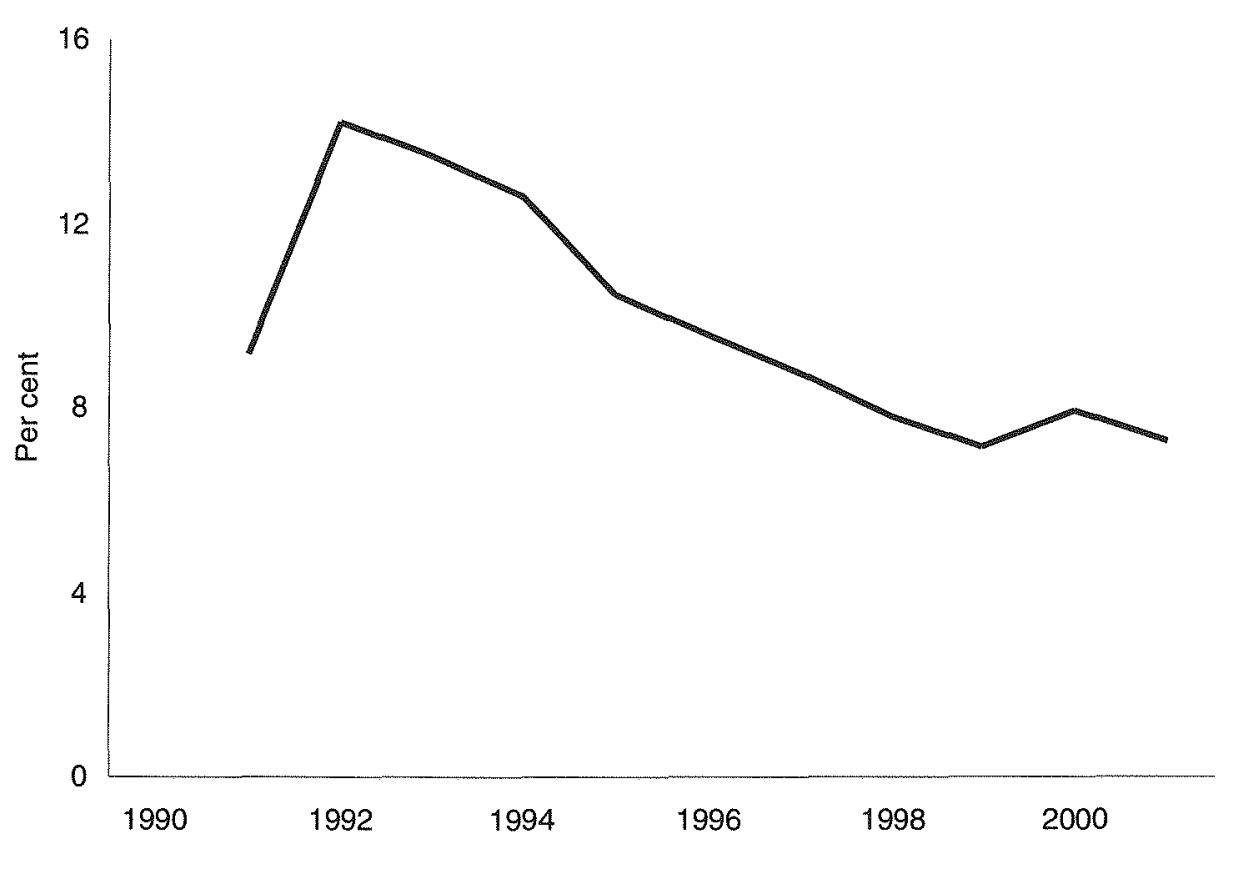

Source: National Statistical Bureau, 2002. China Statistical Yearbook 2002, China Statistics Press, Beijing.

\section{MODELLING EFFECTS OF TRADE POLICY REFORMS}

Here we complement the work of Rees and Tyers (2002) by simulating the short-run effects of trade reforms in China while accounting for the implications of services trade commitments as well as productivity changes associated with these reforms. As in Rees and Tyers (2002) and lanchovichina and Martin (2002), we make allowance for idiosyncratic trade policies, such as the duty drawbacks on imports used in the manufacture of exported goods. As befits a short-run analysis, we also allow for labour market rigidity and associated departures from full employment.

Following Yang and Tyers (2000), we use a comparative static global macroeconomic model, within which the microeconomic (supply) side is adapted from GTAP, ${ }^{12}$ a multi-region comparative static model in real variables with price-taking households and all industries comprising identical competitive firms. To this microeconomic 
Figure 14.5 Official growth rate of the average real manufacturing wage, 19962001 (per cent per annum)

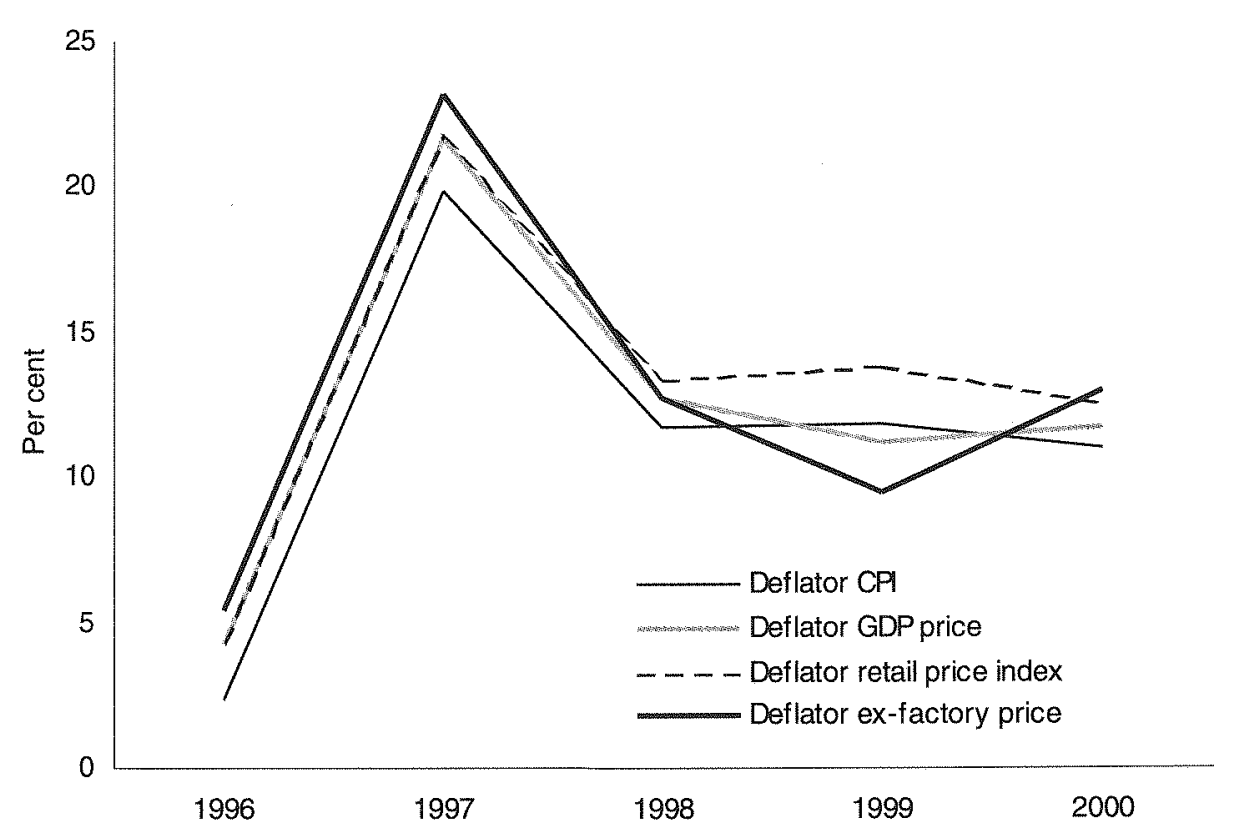

Source: National Statistical Bureau, 2002. China Statistical Yearbook, 2002, China Statistics Press, Beiling: Tables 5-22 and 9-1.

Table 14.1 Official price level changes since the Asian crisis

\begin{tabular}{lcccc}
\hline & Consumer prices & Retail prices & Ex-factory prices & GDP deflator \\
1997 & 2.8 & 0.8 & -0.3 & 0.9 \\
1998 & -0.8 & -2.6 & -4.1 & -2.6 \\
1999 & -1.4 & -3.0 & -2.4 & -2.4 \\
2000 & 0.4 & -1.5 & 2.8 & 1.0 \\
2001 & 0.7 & -0.8 & -1.3 & 0.0 \\
\hline
\end{tabular}

Source: Source: National Statistical Bureau, 2002. China Statistical Yearbook, 2002, China Statistics Press, Beijing: Tables 3-3 and 9-1. 
base are added independent representations of governments' fiscal regimes, with both direct and indirect taxation, as well as separate assets in each region (currency and bonds) and monetary policies with a range of alternative targets.

\section{The model}

The microeconomic side of the model is a modified version of that created by Hertel (1997). It offers the following useful properties

- a capital goods sector in each region to service investment

- explicit savings in each region, combined with open regional capital accounts that permit savings in one region to finance investment in others

- multiple trading regions, goods and primary factors

- product differentiation by country of origin

- empirically based differences in tastes and technology across regions

- non-homothetic preferences

- explicit transportation costs and indirect taxes on trade, production and consumption.

All individual goods and services entering final and intermediate demand are constant elasticity of substitution (CES) blends of home products and imports. In turn, imports are CES composites of the products of all regions, the contents of which depend on regional trading prices. Savings are pooled globally and investment is then allocated between regions from the global pool. Within regions, investment places demands on the domestic capital goods sector, which is also a CES composite of home-produced goods, services and imports in the manner of government spending.

To expand the model for macroeconomic analysis, the standard code is modified to make regional governments financially independent, thus enabling explicit treatment of fiscal policy. Direct taxes are incorporated at the observed average income tax rates for each region. Marginal tax rates are therefore assumed constant (say at $t$ ). Regional households then receive regional factor income, $Y_{F}$, and from this they pay direct tax $t Y_{F}$. The disposable income that remains is then divided between private consumption and private saving. Government saving, or the government surplus, $S_{G}=T-G$, is then simply revenue from direct taxes, $t Y_{F}$, and from the many indirect taxes already incorporated in the microeconomic part of the model ${ }^{13}, T_{p}$ less government spending, $G$, which could be exogenous or fixed as a proportion of GDP. Thus, $S_{G}=T_{1}+t Y_{F}-G$. The private saving and consumption decision is represented by a reduced form exponential consumption equation with 
wealth effects included via the dependence of consumption (and hence savings) on the interest rate. Each region then contributes its total domestic (private plus government) saving, $S_{D}=S_{P}+S_{G}$, to the global pool from which investment is derived. ${ }^{14}$

For each region, the above relations imply the balance of payments identity, which sets the current account surplus equal to the capital account deficit: $X-M=S_{p}+$ $S_{G}-1 .{ }^{15}$ From the pool of global savings, investment is allocated across regions and places demands on capital goods sectors in each region. In the short run however, investment does not add to the installed capital stock. Also at this length of run, nominal wages are sticky in some regions (the industrialised regions of the United States, the European Union, Canada and Australia, and those developing countries with heavily regulated labour markets: China and Vietnam) but flexible elsewhere. In the spirit of comparative statics, although price levels do change in response to shocks, agents represented in the model do not expect any continuous inflation and so there is no distinction between the real and nominal interest rates.

In allocating the global savings pool as investment across regions, we have opted for the most flexible approach, implying a high level of global 'capital' mobility. ${ }^{16}$ Where controls exist on international capital flows we introduce these explicitly. In the absence of capital controls, the allocation to region $j$ (net investment in that region) depends positively on the expected long-run change in the average rate of return on installed capital, $r_{j}^{\ominus}$, which, in turn, rises when the marginal product of physical capital is expected to increase. ${ }^{17}$ Net investment falls when the opportunity cost of financing capital expenditure, the region's real interest rate, $r_{f}$ rises. This rate depends, in turn, on a global capital market clearing interest rate, $r^{w}$, calculated such that global savings equals global investment $: \Sigma_{j} S_{j}^{D}=\Sigma_{j} I_{j}\left(r_{j}^{\theta}, r_{j}\right)$. Here $I_{j}$ is real gross investment in region $j .{ }^{18}$ The region's home interest rate is then $r_{j}=r^{N}\left(1+p_{j}\right)$ where $p_{j}$ is a region-specific interest premium, thought to be driven by risk factors not incorporated in this analysis. The investment demand equation for region $j$ then takes the form:

$$
I_{j}=\delta_{j} K_{j}+I_{j}^{N}=\delta_{j} K_{j}+\beta_{j} K_{j}\left(\frac{r_{j}^{e}}{r_{j}}\right)^{\varepsilon_{j}}=K_{j}\left[\delta_{j}+\beta_{j}\left(\frac{r_{j}^{e}}{r_{j}}\right)^{\varepsilon_{j}}\right]
$$

where $K_{j}$ is the (exogenous) base year installed capital stock, $d_{j}$ is the regional depreciation rate, $b_{j}$ is a positive constant and $e_{j}$ is a positive elasticity. Critically, investment in any region responds positively to changes that are expected to raise 
the sectoral average of a region's marginal product of physical capital and hence the regional average return on installed capital. ${ }^{19}$ Other things being equal, improvements in trans-sectoral efficiency, such as might stem from a trade reform, are thought to raise capital returns permanently and hence they raise $r_{j}^{e}$. If such a shock also causes the rate of unemployment to fall, this raises total labour use and hence the current return on installed physical capital. When the shock is a trade reform, such employment effects are also considered permanent and so they add positively to the expected future return on installed capital, $r_{j}^{\theta}$.

Investment decisions are made by forward-looking agents with access to a longrun version of the model. Thus, the expected change in the (long-run) rate of return on installed capital in each region, $r_{j}^{\theta}$, is exogenous in short-run simulations. It is calculated by first simulating the effects of the same shock but under long-run closure assumptions. These differ from the short-run closure in the following ways

- there are no nominal rigidities (no rigidity of nominal wages)

- larger production and consumption elasticities are used to reflect the additional time for adjustment

- physical capital is no longer sector specific; it moves across sectors to equalise rates of return

- capital controls are ignored

- in China, irrespective of short-run fiscal policy assumptions, in the long run any loss of government revenue associated with tariff changes is assumed not to be made up via direct (income) tax, with the result that the fiscal deficit expands; thus, the ratios of government revenue and expenditure to GDP are endogenous while the average direct tax rate is exogenous.

Note that the short-run comparative static analysis does not require the global economy to be in a steady state. When shocks are imposed, any change in the counterfactual return on installed capital, $r_{j}^{\theta}$, need not be the same as the corresponding change in the opportunity cost of capital expenditure, $r_{j}$ Most often, short-run shocks change income and savings and, therefore, expected returns in directions that differ from corresponding short-run changes in the global interest rate, particularly considering that physical capital is fixed in quantity and sectoral distribution at this length of run. Even in long-run simulations, the global distribution of physical capital at the outset does not equalise rates of return across regions, and redistribution through the regional allocation of one year's global savings is insufficient to redress such imbalances. 
To include asset markets, region-specific money and nominal bonds are introduced. Even though there is no interregional ownership of installed capital in the initial database, regional bonds are traded internationally, making it possible for savers in one region to finance investment in another. ${ }^{20}$ Cash constraints cause households to maintain portfolios including both bonds and non-yielding money and the resulting demand for real money balances has the usual reduced form dependence on GDP (transactions demand) and the interest rate. This is equated with the region's real money supply, where purchasing power is measured in terms of its GDP deflator, $P^{Y}$. Since all domestic transactions are assumed to use the home region's money, international transactions require currency exchange. For this purpose, a nominal exchange rate, $E_{j}$, is defined for each region. A single key region is identified (here the United States), relative to whose currency these nominal rates are defined. For the United States, then, $E=1$ and $E_{j}$ is the number of US dollars per unit of region $j$ s currency. In essence, we are adding to the real model one new equation per region (the LMcurve linking the real money supply to GDP and the interest rate) and one new (usually endogenous) variable per region, $E_{j}{ }^{21}$ The bilateral rate between region $i$ and region $j$ is then simply the quotient of the two exchange rates with the United States, $E_{i j}=E_{i} / E_{j}$. Quotients such as this appear in all international transactions.

Without nominal rigidities the model always exhibits money neutrality, both at the regional and global levels. Firms in the model respond to changes in nominal product, input and factor prices but a real producer wage is calculated for labour as the quotient of the nominal wage and the GDP deflator, so that $W=W / P^{Y}$. Money shocks always maintain constant $w$ when nominal rigidities are absent. To make possible some rigidity in the setting of the nominal wage, $W$, a parameter, $\lambda \in(0,1)$ is inserted, such that

$$
\frac{W}{W_{0}}=\Lambda\left(\frac{P^{C}}{P_{0}^{C}}\right)^{\lambda}
$$

where $W_{0}$ is the initial value of the nominal wage, $P_{0}^{C}$ is the corresponding initial value of the consumer price index (CPI) and $\lambda$ is a constant. Whenever $\lambda$ is exogenous and set at unity, the nominal wage carries this relationship to the CPI and the labour market will not clear except in the unlikely event that Equation 14.3 happens to yield a market-clearing real wage. The case where the labour market is fully flexible is represented by setting $\lambda$ as an endogenous slack variable and thereby rendering 
Equation 14.3 ineffective. At the same time, labour demand is forced to equate with exogenous labour supply to reflect the clearing market.

The representation of capital controls. Savings are assumed to be perfectly mobile between regions. The allocation of investment between them depends on regionspecific interest premia and, if they are present, capital controls. In the absence of capital controls, a region's domestic capital market might be represented as in Figure 14.6. Net inflows on the capital account $(K A)$, which comprise the net inflow of private foreign savings, less the net outflow associated with the accumulation of official foreign reserves, $\Delta R$, depend on the domestic bond rate, which deviates from a global capital market clearing interest rate by the risk premium factor $1+\pi .^{22}$ The KA curve slopes upward slightly in spite of the assumed perfect capital mobility because larger net inflows to the focus region drive up the global market-clearing interest rate.

The actual scale of net inflows depends on the net demand for foreign investment, $N F I=I-S_{D}$, where the relationship between $N F I$ and $r$ is shifted to the right by an increase in the expected future return on installed capital, $r$, via Equation 14.2, or by an increase in government spending, $G$, via its effect on domestic saving. It is shifted to the left by an increase in GDP ( $Y$ ), via its effect on consumption and tax revenue and hence on domestic savings, $S_{D}$. In the figure, net outflows on the capital account are determined by the intersection of the two curves shown. For a balance of payments, these outflows must then equate to net inflows on the current account, $C A$, and prices, and therefore real exchange rates, adjust to ensure that this is the case.

In this analysis, capital controls take the form of a rigid ceiling on net outflows on the capital account (Figure 14.7), severing the link between the home and global interest rates unless net foreign investment rises sufficiently for the controls no longer to be binding. To capture this in model simulations, the interest premium, $\pi$, is made endogenous while net flows on the capital account, $K A$, or, equivalently, on the current account, $C A$ (where $B O P=K A+C A=0$ ), are set as exogenous.

Data and parameters. The regions, primary factors and sectors identified in our analysis are listed in Table 14.2. Considering regions first, we draw on the now wellknown GTAP Version 5 global database for 1997, which divides the world into 66 countries and regions. Although this database separates mainland China from Taiwan, it amalgamates Hong Kong with the mainland. ${ }^{23}$ Our further aggregation of mainland China with Taiwan overlooks effects that are internal to these regions, but such 


\section{Table 14.2 Model structure}

\section{Regions}

1. China, including Hong Kong and Taiwan

2. Vietnam

3. Other ASEAN

4. Japan

5. Korea

6. Australia

7. United States

8. European Union ${ }^{a}$

9. Rest of world

\section{Primary factors}

1. Agricultural land

2. Natural resources

3. Skill

4. Labour

5. Physical capital

Sectors ${ }^{b}$

1. Paddy rice

2. Beverages (product 8 OCR, 'crops nec')

3. Other crops (wheat, other cereal grains, vegetables, fruits, nuts, oil seeds, sugar cane and sugar beet, plant-based fibres and forestry)

4. Livestock products (cattle, sheep, goats, horses, wool, silk-worm cocoons, raw milk, other animal products)

5. Fish (marine products)

6. Energy (coal, oil, gas)

7. Minerals

8. Processed food (meat of cattle, sheep, goats and horses, other meat products, vegetable oils and fats, dairy products, processed rice, processed sugar, processed beverages and tobacco products)

9. Light manufacturing (textiles, wearing apparel, leather products and wood products)

10. Other manufacturing (paper products and publishing, petroleum and coal products, chemicals, rubber and plastic products, other mineral products, ferrous metals, other metals, metal products, motor vehicles and parts, other transport equipment, electronic equipment, other machinery and equipment, other manufactures)

11. Transport (sea transport, air transport and other transport)

12. Infrastructure services (electricity, gas manufacturing and distribution, and water)

13. Construction and dwellings

14. Other services (retail and wholesale trade, communications, insurance, other financial services, other business services, recreation, other private services, public administration, defence, health and education)

Notes: ${ }^{a}$ The European Union of 15. ${ }^{\mathrm{b}}$ These are aggregates of the 57 -sector GTAP Version 5 database. 
Figure 14.6 The domestic capital market without capital controls

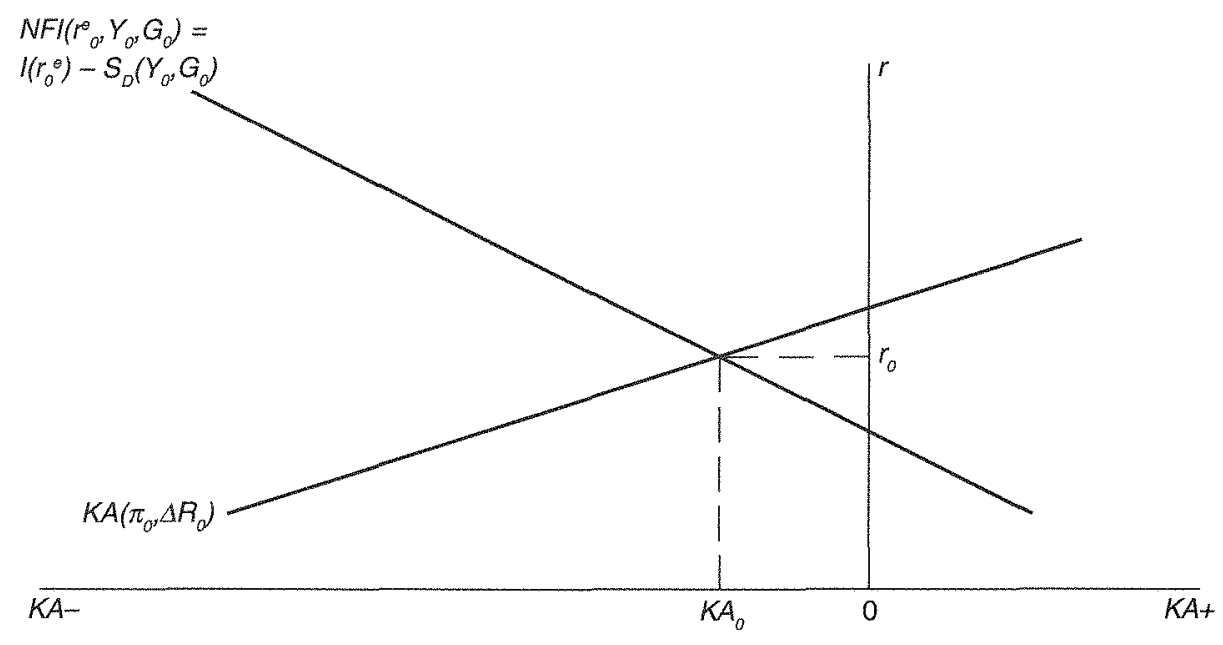

Figure 14.7 The domestic capital market with capital controls

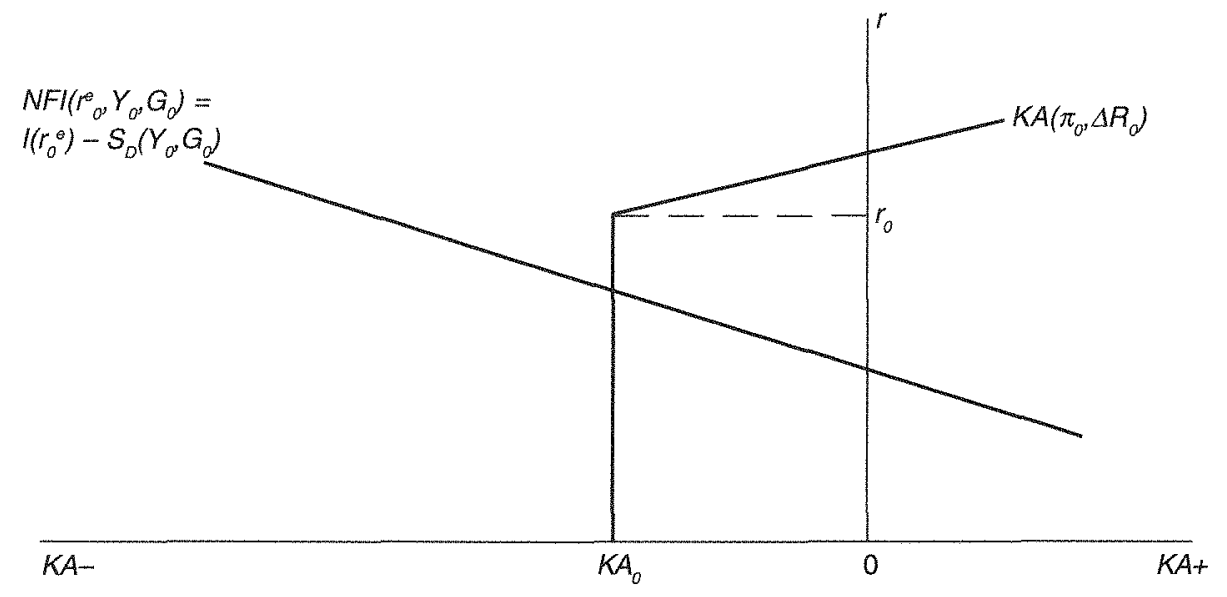


effects are not our focus. Instead, we seek to illustrate the strong interaction between trade reforms and macroeconomic policies, and, particularly, foreign exchange regimes. These interactions are important for all the economies of East Asia and particularly for those with regulated foreign exchange regimes. China is the largest developing economy to maintain, at least de facto, fixed US dollar parity and, in this respect, the macroeconomic policy regimes of Hong Kong (and to a much lesser extent) Taiwan have been compatible with that of the mainland.

Turning to primary factors, skill is separated from raw labour on occupational grounds, with the 'professional' categories of the International Labour Organisation (ILO) classification included as skilled. ${ }^{24}$ The structure of factor demand has skill and physical capital as complements. This enables the model to represent the links between skill availability, capital returns and investment that are important in China, which has large skilled and unskilled labour forces that are increasingly mobile between sectors. ${ }^{25}$ Finally, the sectoral breakdown we have chosen aggregates the 57 sectors in the database to our more manageable 14, offering the most delail in agricultural and marine products. This is because, amongst China's merchandise trade commitments for WTO accession, a key liberalisation is in the processed food sector, to which these commodities are inputs.

Because the length of run is short, the real part of the short-run model incorporates smaller-than-standard elasticities of substitution in both demand and supply. These are set on the basis of a short-run calibration exercise on the East Asian crisis, described in Yang and Tyers (2000). For further details of the model, its parameters and its structure, see Yang and Tyers (2000) and Tyers and Yang $(2000,2001)$.

\section{Representing post-crisis trade policies and reforms}

A key change since 1997 is the introduction of duty drawbacks offered to firms on the component of their imports that is used for export production. The approach taken is detailed in Tyers and Rees (2002). Table 14.3 presents the pattern of equivalent trade taxes and subsidies as of 2001 and as anticipated post-accession. To obtain the rates in Table 14.3, the industry classification used in the WTO list of tariff concessions was concorded with the cruder subdivision used in our model and average rates constructed for each sector. The information contained in the database was supplemented by details of the accession tariff rates provided by lanchovichina and Martin (2001). To represent the behavioural impacts of the changes in equivalent tariff rates as accurately as possible, emphasis was placed on preserving changes 
in the 'powers of the tariffs' rather than in the rates themselves. ${ }^{26}$

The equivalent Chinese tariff rates of the 1990s vary by country of origin. This means that the application of the same shock to the powers of these equivalent tariffs might have led to negative post-accession rates for some trading partners. The accession shocks to the equivalent bilateral tariff rates were therefore calculated so as to harmonise the post-shock tariff rates across countries of origin. The proportional changes in 'powers of equivalent tariffs' are the same as those implied by the changes in rates detailed in lanchovichina and Martin (2002). For our present purpose, these shocks are the same for both the long run and the short run. As indicated in the WTO database, China is committed to undertaking many of the tariff concessions immediately on accession. ${ }^{27}$

Table 14.3 Chinese equivalent import tariff and export tax rates ${ }^{\mathrm{a}}$

\begin{tabular}{lccc}
\hline \multicolumn{4}{c}{$\begin{array}{c}\text { Equivalent import tariff } \\
\text { (per cent) }\end{array}$} \\
Rice & \multicolumn{2}{c}{$\begin{array}{c}\text { Post-accession } \\
\text { Pre-accession }\end{array}$} & $\begin{array}{c}\text { Pqivalent export tax } \\
\text { (per cent) }\end{array}$ \\
Beverages & 0.04 & 0.04 & -0.13 \\
Other crops & 11.00 & 11.00 & -0.11 \\
Livestock & 22.00 & 16.00 & -0.25 \\
Food & 5.00 & 4.00 & -0.02 \\
Fish & 16.00 & 6.00 & -0.13 \\
Minerals & 8.00 & 8.00 & -0.19 \\
Energy & 0.40 & 0.40 & -0.32 \\
Light manufacturing & 3.00 & 3.00 & -0.32 \\
Heavy manufacturing & 14.00 & 8.00 & 2.63 \\
& 8.00 & 4.00 & -1.01 \\
\hline
\end{tabular}

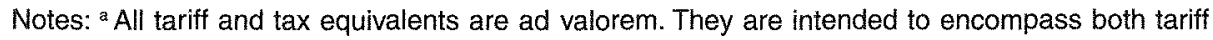
and non-tariff barriers, though the accounting for non-tariff barriers is incomplete. Services distortions are not generally included in the database. See text of a discussion of their representation in the analysis. ${ }^{b}$ Negative export tax rates indicate export subsidies. These incorporate the export subsidy equivalents of the duty drawbacks available on imported inputs by exporting firms, calculated as explained in the text.

Sources: The original 1997 numbers are aggregated from the 57 commodity categories in the GTAP Version 5 global database (as published in 2000). They are then modified using model simulations, as described in the text and based on the work of lanchovichina and Martin (2002), to obtain pre-accession estimates for 2001. Finally, the post-accession rates are based on the protocol for China's accession, as obtained from the WTO website at http://www.wto.org. 


\section{SIMULATED EFFECTS OF ACCESSION POLICY REFORMS}

The reasons for examining long-run implications first are twofold. First, the long-run results are useful in their own right, given that they may then be compared with the many other simulations of China's WTO accession reforms. Second, the long-run outlook is required in order that the expectations of investors can be formulated for short-run analysis. Recall that investors are assumed to take into account changes in long-run returns on installed capital in determining short-run changes in their investment behaviour.

Recapping the key elements of long-run closure

- there are no nominal rigidities (no rigidity of nominal wages)

- production and consumption elasticities of substitution are chosen at long-run levels to reflect the additional time for adjustment in the long run over the short run

- physical capital is no longer sector specific; it redistributes across sectors to equalise rates of return

- capital controls are ignored, and

- in China, irrespective of short-run fiscal policy assumptions, in the long run any loss of government revenue associated with tariff changes is assumed to not be made up via direct (income) tax, with the result that the fiscal deficit expands.

The key point of difference between our long-run analysis and that of Rees and Tyers (2002) is that we represent the effects of trade reforms on productivity. There is a substantial literature identifying this association (Chand et al. 1998; Chand 1999; Stoeckel et al. 1999). These studies use Australian data on the long-run effects of trade reforms to identify elasticities of total factor productivity to protection level by industry. We applied these elasticities to China's intended reforms, albeit with discounts for China's lower starting protection levels in some industries and adjustments to account for services sector reforms (Dee and Hanslow 2000; Verikios and Zhang 2001), to yield the one-off long-run productivity shocks listed in Table 14.4. Although these shocks are applied only in the long run, they are important for short-run behaviour (our object here) because they raise the return on installed capital and hence stimulate investment.

The results from the long-run simulation are provided in Table 14.5. They show the expected allocative efficiency gains, reflected here in a rise in GDP, aided by 
increased returns on installed physical capital that induce greater investment and therefore larger net inflows on the capital account in the long run. As home consumption switches away from home-produced goods, the relative prices of homeproduced goods fall yielding the predicted real depreciation. The principal downside of the reforms is the long-run shift of activity out of agriculture into manufacturing and services and the associated decline in land rents. Associated with this shift, further substantial relocation of workers from agriculture to the modern sector will therefore be required.

Although the trade policy regime of 2001 advantaged food processing, 'other crops', fisheries and light manufacturing, it is the manufacturing sectors that are the robust beneficiaries of the unilateral trade liberalisation. This is surprising given that the

Table 14.4 Ancillary effects of WTO trade reforms ${ }^{\mathrm{a}}$

\begin{tabular}{|c|c|c|}
\hline & $\begin{array}{l}\text { Long-run total } \\
\text { factor productivity } \\
\text { rises associated with } \\
\text { reduced protection } \\
\text { (per cent) }\end{array}$ & $\begin{array}{l}\text { Short-run effect of } \\
\text { reduced services } \\
\text { protection on capital } \\
\text { accumulation in } \\
\text { finance and } \\
\text { communications } \\
\text { (per cent/year) }\end{array}$ \\
\hline Rice & 1.0 & \\
\hline Beverages & 1.0 & \\
\hline Other crops & 1.0 & \\
\hline Livestock & 1.0 & \\
\hline Food & 2.0 & \\
\hline Fish & - & \\
\hline Minerals & - & \\
\hline Energy & - & \\
\hline Light manufacturing & 1.5 & \\
\hline Heavy manufacturing & 3.0 & \\
\hline Transport services & 1.0 & \\
\hline Infrastructural services (electricity, gas, water) & 1.0 & \\
\hline Construction and dwellings & 2.0 & \\
\hline Other (including financial and communications) & 5.0 & 2.0 \\
\hline
\end{tabular}

Notes: a These are supplementary exogenous shocks applied, where indicated, along with the tariff reductions. They incorporate the findings of other research, particularly on the effects of services reform. ${ }^{\circ}$ Estimates based on the results from research by Chand et al. (1998), Chand (1999) and Stoeckel et al. (1999). " Estimated one-year effect, based on the results from research by Dee and Hanslow (2000) and Verikios and Zhang (2001).

Sources: As specified in the notes above. 
Table 14.5 Simulated long-run effects of a unilateral liberalisation of China's 2001 trade policy regime ${ }^{a}$

\begin{tabular}{|c|c|c|}
\hline Change in & $\begin{array}{l}\text { No ancillary effects } \\
\text { on productivity or } \\
\text { services capital }\end{array}$ & $\begin{array}{l}\text { With ancillary effects } \\
\text { on productivity and } \\
\text { services capital }^{b}\end{array}$ \\
\hline Terms of trade (per cent) & -1.25 & -1.52 \\
\hline Real effective exchange rate, $e_{i}^{A}$ (per cent) & -1.98 & -2.56 \\
\hline Real exchange rate against USA, $e_{i j}{ }^{F}$ (per cent) & -1.81 & -2.37 \\
\hline Global interest rate, $r^{w}$ (per cent) & 0.10 & 0.05 \\
\hline Investment premium factor, $(1+\dot{A})$ (per cent) & 0.00 & 0.00 \\
\hline Home interest rate, $r$ (per cent) & 0.10 & 0.05 \\
\hline Return on installed capital, $r^{c}$ (per cent) ${ }^{c}$ & 1.30 & 4.98 \\
\hline Real domestic investment, I (per cent) & 0.95 & 3.85 \\
\hline Balance of trade, $X-M=-K A=-\left(1-S_{D}\right)$ (US\$ bn) & -10.87 & -5651 \\
\hline \multicolumn{3}{|l|}{ Real gross sectoral output (per cent) } \\
\hline Rice & -3.29 & -2.54 \\
\hline Beverages & 2.77 & 3.33 \\
\hline Other crops & -1.25 & -0.36 \\
\hline Livestock & 0.03 & 1.32 \\
\hline Food & -5.41 & -4.32 \\
\hline Fish & -0.17 & 0.35 \\
\hline Minerals & 0.88 & 2.38 \\
\hline Energy & 0.78 & 0.95 \\
\hline Light manufacturing & 1.49 & 2.26 \\
\hline Heavy manufacturing & 1.08 & 4.60 \\
\hline Transport & 1.44 & 2.87 \\
\hline Infrastructure services & 0.34 & 2.25 \\
\hline Construction and dwellings & 0.73 & 3.46 \\
\hline Other services & 0.76 & 4.96 \\
\hline Real GDP, $Y$ & 0.41 & 3.31 \\
\hline \multicolumn{3}{|l|}{ Unskilled wage and employment (per cent) } \\
\hline Nominal (unskilled) wage, $W$ & -0.42 & 1.85 \\
\hline Production real wage, $w=W / P^{r}$ & 1.51 & 4.53 \\
\hline Employment, $L^{D}$ & 0.00 & 0.00 \\
\hline \multicolumn{3}{|l|}{ Unit factor rewards CPI deflated (per cent) } \\
\hline Land & -2.65 & -1.39 \\
\hline Unskilled labour (those employed) & 1.27 & 4.08 \\
\hline Skilled labour & 1.38 & 4.22 \\
\hline Physical capital & 1.24 & 4.04 \\
\hline Natural resources & 1.20 & 2.65 \\
\hline
\end{tabular}

Notes: a All results in table are based on the assumption that government spending is held constant as a share of GDP; revenue lost from tariff reform is not made up in other taxes, so the fiscal deficit expands. Key exogenous variables are highlighted as per the long-run closure discussed in the text. ${ }^{b}$ For these additional shocks, see Table 14.4.

Source: Model simulations described in the text. 
protection of the manufacturing sectors is also set to decline. It is because both manufacturing sectors commit approximately half their total costs to inputs in the same product category and about 10-15 per cent of those committed to imports. Competing imports, even though they are from the same sector, are differentiated from home products (Rees and Tyers 2002). Under these conditions, the tariff reductions on imported intermediates have a direct effect on home industry total cost. Reductions to tariffs on competing, but differentiated, imports have only an indirect effect, the magnitude of which depends on the elasticity of substitution between the two. Indeed, for manufacturing, it turns out that the effect of tariff reductions on input costs is considerably greater than that of the loss of protection against competing imports. Cost reductions of similar origin are the reason for similar gains accruing to the domestic transport services sector.

The reforms cause the most substantial reductions in protection to China's food processing sector and therefore lead to long-run contractions in that sector and in the local supply of its inputs (especially rice and 'other crops'). The more income elastic and lightly protected agricultural sectors, the 'beverages' group and livestock, actually expand. Labour is assumed to be perfectly mobile between sectors, so that our results indicate the labour movement needed in order to achieve the maximum gain from the reforms. In the long run, employment in food processing falls by seven per cent, in rice production by four per cent and in 'other crops' by two per cent. Workers lost from these sectors are re-employed primarily in manufacturing and services.

When reform-driven productivity improvements are included in the long-run analysis, even though the assumed productivity changes are one-off and modest, the economic effects of the reforms are greatly amplified. The GDP increase is almost ten times larger, while domestic investment is four times larger, as is the return on installed capital, which will drive short-term investment. Increases in sectoral expansions are largest in manufacturing and services, the productivity of services having widespread effects through their role as intermediates. The overall contraction in the agricultural sector is much reduced, with the beverages, livestock and fisheries sectors now showing robust expansions.

\section{Simulated short-run effects}

In the short run, for all the regions represented, the standard closure is as indicated in Table 14.6. Monetary authorities in China, Vietnam and the rest of the world are 
assumed to maintain fixed exchange rates against the US dollar. The other regions identified adopt price level (CPI) targeting. Capital controls are assumed to be rigid in China and Vietnam, but non-existent in the other regions. In the labour markets of China and Vietnam nominal wages are assumed to be 'sticky'. Full short-run rigidity is assumed in the industrial countries, while nominal wages are assumed to be fully flexible elsewhere in Asia and the developing world. As to fiscal policies (not shown in Table 14.6), government spending in all regions is assumed to absorb a fixed proportion of GDP and the rates of direct and indirect tax are assumed to be constant, so that government deficits do vary in response to shocks.

As indicated earlier, three alternative macroeconomic policy regimes are considered.

\section{Table 14.6 Short-run closure ${ }^{a}$}

\begin{tabular}{|c|c|c|c|}
\hline Region & Monetary policy target ${ }^{b}$ & $\begin{array}{c}\text { Labour market } \\
\text { closure: nominal } \\
\text { wage }^{c o}\end{array}$ & $\begin{array}{l}\text { Capital controls: } \\
\text { capital account } \\
\text { net inflow } /-S_{D}{ }^{d}\end{array}$ \\
\hline China (1) & Nominal exchange rate, $E$ & Sticky $(l=0.5)$ & Rigid \\
\hline China (2) & Nominal exchange rate, $E$ & Sticky $(\mid=0.5)$ & Flexible \\
\hline China (3) & GDP price, $p^{r}$ & Sticky $(l=0.5)$ & Flexible \\
\hline Vietnam & Nominal exchange rate, $E$ & Sticky $(l=0.5)$ & Rigid \\
\hline Other ASEAN & Consumer price level, $P^{c}$ & Flexible $(l=1)$ & Flexible \\
\hline Japan & Consumer price level, $P^{c}$ & Sticky $(l=0.5)$ & Flexible \\
\hline Korea & Consumer price level, $P^{c}$ & Flexible $(=1)$ & Flexible \\
\hline Australia & Consumer price level, $P^{c}$ & Sticky $(l=0.5)$ & Flexible \\
\hline United States & Consumer price level, $P^{c}$ & Sticky $(l=0.5)$ & Flexible \\
\hline Europe (EU) & Consumer price level, $P c$ & Rigid $(l=0)$ & Flexible \\
\hline Rest of world & Nominal exchange rate, $E$ & Flexible $(l=1)$ & Flexible \\
\hline \multicolumn{4}{|c|}{$\begin{array}{l}\text { Notes: }{ }^{a} \text { The expected future return on installed capital is exogenous in the short run, determined } \\
\text { in a separate long-run solution. There are three macroeconomic policy regimes for China, with (1) } \\
\text { the most restrictive and ( } 3 \text { ) the most expansionary. }{ }^{b} \text { The nominal money supply is endogenous in } \\
\text { each case, the corresponding exogenous variable being the listed target. " When the nominal } \\
\text { wage is assumed flexible it is endogenous and the corresponding exogenous variable is the } \\
\text { employment level. When it is sticky or rigid, Equation } 14.2 \text { is activated and the employment level is } \\
\text { endogenous. }{ }^{d} \text { Capital controls are assumed to maintain a rigid net inflow of foreign investment on } \\
\text { the capital account. When } K A=I-S_{D} \text { is made exogenous to represent this, an interest premium } \\
\text { opens between the domestic and international capital markets. This premium becomes } \\
\text { endogenous. Effectively, the home and foreign capital markets are separated and clear at different } \\
\text { interest rates. Where the capital account is flexible (open), this implies that private flows on the } \\
\text { capital account are permitted at any level. } K A=1-S_{D} \text { is then endogenous and the home interest } \\
\text { premium is exogenous (unchanged by any shock). This means that the home interest rate then } \\
\text { moves in proportion to the rate that clears the global savings-investment market. }\end{array}$} \\
\hline
\end{tabular}


- The 'standard'-rigid capital controls with a fixed exchange rate.

- No capital controls and a fixed exchange rate.

- No capital controls, a floating exchange rate and monetary policy targeting the GDP price.

In addition, two alternative assumptions are made about investment and the services capital stock. In a pessimistic alternative, investors do not see the longrun benefits of productivity gains that would accompany trade reform, and there is no immediate effect from reforms in services trade. In an optimistic counterpart, investors are motivated by the long-run return on installed capital listed in the second column of Table 14.5. Moreover, drawing on the conclusions from studies by Dee and Hanslow (2000) and Verikios and Zhang (2001), service trade reforms are assumed to result in the short run bolstering of the capital stock in finance and communications indicated in Table 14.4. Not surprisingly, the short-run effects of China's WTO commitments prove to be heavily dependent on her macroeconomic policy regime and the associated productivity and capital stock changes. Indeed, the effects range from the contraction alluded to in the introduction through to a substantial short-run expansion.

\section{The effects of capital controls and the choice of monetary policy target}

The broad behaviour of the model in the short run with rigid capital controls retained can be represented as in Figure 14.8. The upper diagram represents the domestic capital market and the lower diagram the domestic market for foreign products. These markets are linked by the requirement that, for a balance of payments, net flows on the capital account must mirror those on the current account. Net demand for foreign products (the downward sloping line in the lower diagram, $N M=M-X$ ) depends on the relative price of foreign goods. For this purpose, we define the real exchange rate (Equation 14.1) as the common currency ratio of the price of home goods to the price of foreign goods. Net imports depend positively on this real exchange rate and negatively on its inverse (the common-currency foreign to home product price ratio). This excess demand curve is shifted to the right by an increase in GDP, $Y$, or a reduction in protection, $\tau$. The real exchange rate is then determined by the balance of payments requirement that net inflows on the capital account must equal net outflows on the current account, $K A=-C A=N M=M-X^{28}$ 
The trade liberalisation reduces $\tau$ and shifts $N M$ to the right. With tight capital controls, the current account balance cannot change. The shock therefore raises the relative price of foreign goods in the home market and thus depreciates the real exchange rate. If the nominal exchange rate is the target of monetary policy and the home economy is small by comparison with its trading partners ( $P^{*}$ is unaffected) then, from Equation 14.4, a fall in $P^{Y}$ (a deflation) is required. This must be brought about by a monetary contraction in defence of the exchange rate. To the extent that wages adjust more sluggishly than product prices, the deflation causes the real wage to rise. Were the real depreciation the only consequence of the liberalisation shock, its effects would therefore be contractionary. Fortunately, this need not be the case. The trade reform brings gains in allocative efficiency. ${ }^{29}$

When capital controls remain rigid and the exchange rate fixed, however, in the Chinese case these allocative gains are insufficient to offset the contractionary effects of the deflation. This can be seen from the first column of Table 14.7. The real depreciation is substantial and the deflation required is of the order of two per cent per year. The production real wage rises by half this and employment falls. In Figure 14.8, investment demand responds to the expectation of higher real returns to installed capital in the future by shifting outward. The loss of tariff revenue drives the government deficit higher, reducing domestic saving, further reinforcing the outward shift of the net foreign investment (NFI) demand curve. But the rigidity of the capital controls causes this to simply push up the domestic interest rate and so real private investment actually falls. Output falls in all sectors except beverages, energy, manufacturing and transport. Manufacturing gains in the short run for the same reasons it gains in the long run-cheaper imported inputs. Under these policy circumstances, then, the overall net gains from trade reform are not robust in the short run, at least when pessimistic assumptions are made about productivity effects and services reform.

If the capital controls are removed, the corresponding liberalisation shock is as depicted in Figure 14.9 and the results are shown in column 2 of Table 14.7. Here, reduced protection also yields a gain in allocative efficiency, but this time the increase is large enough to generate a net gain in GDP, reinforcing the rightward shift in the net imports curve in the lower diagram. In this case, however, the absence of capital controls allows investment to flow in, responding to the increase in the expected long-run return on installed capital. The increased inflow on the capital account 


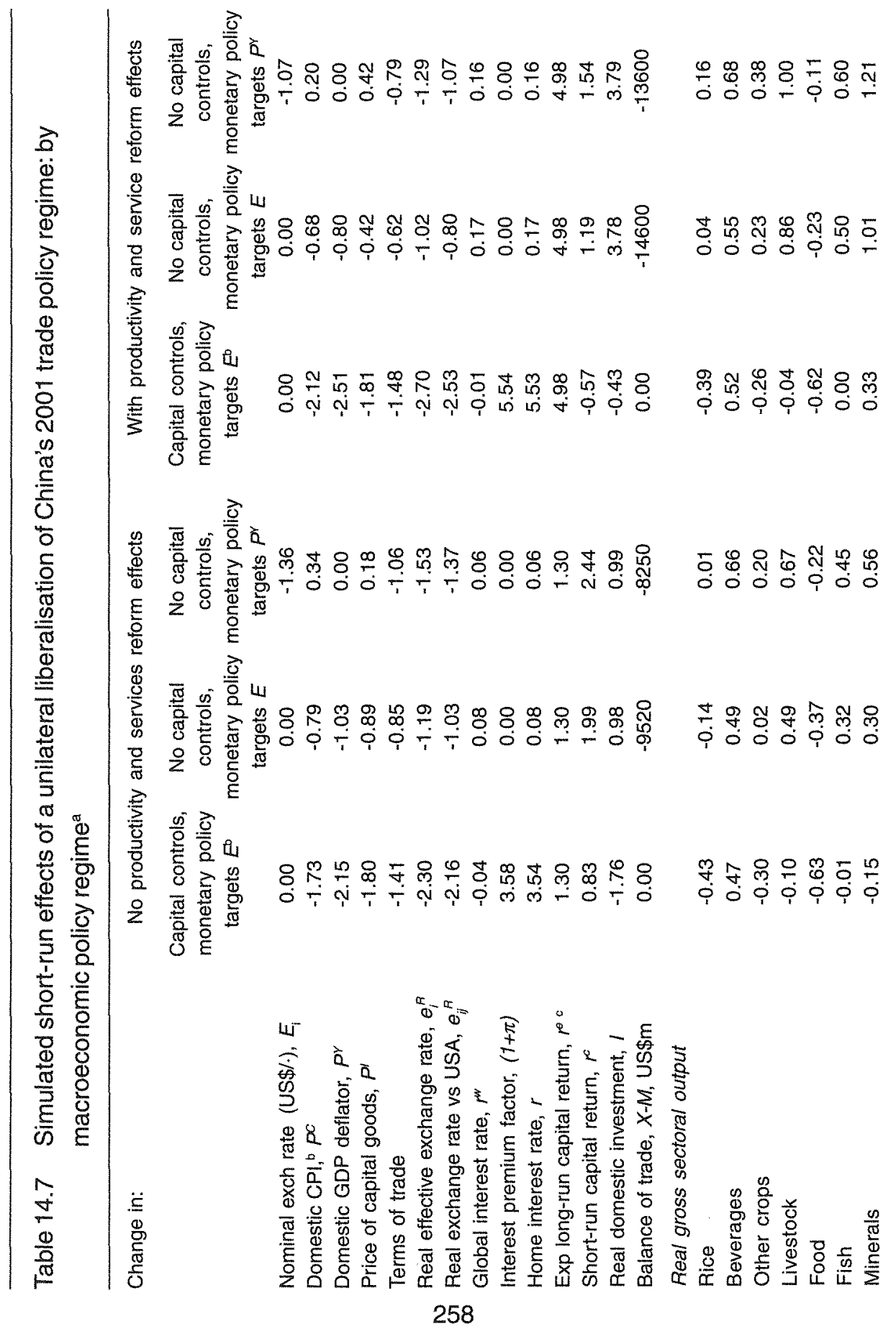




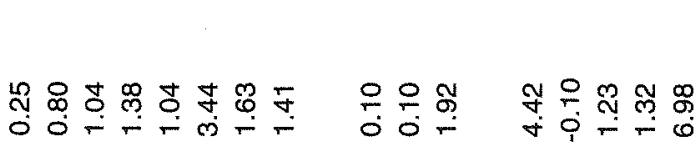

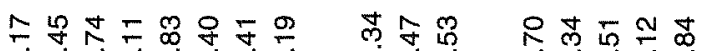

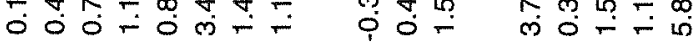

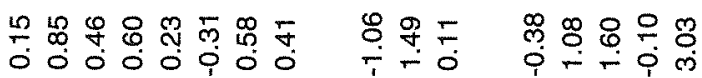

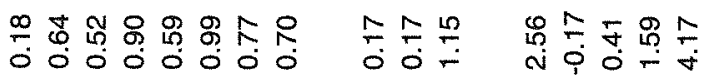

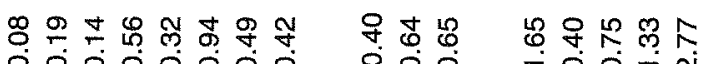

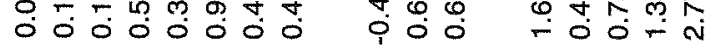

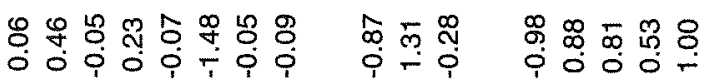

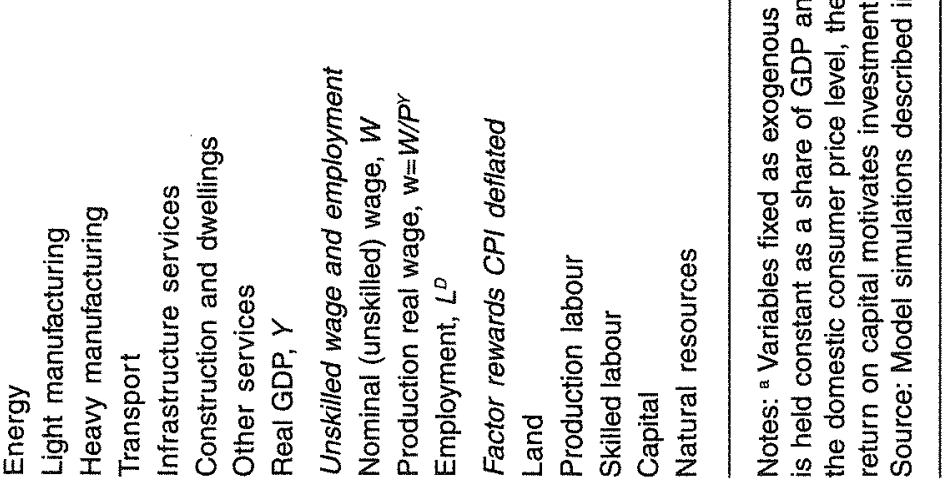


relaxes the balance of payments constraint in the lower diagram and allows a shift toward net imports. The net effect on the real exchange rate depends on whether the capital account shift, which raises the net supply of foreign goods, is larger or smaller than the increase in net demand for them due to the tariff reduction and the rise in domestic income. In the case of China, the rise in net demand is dominant and the real exchange rate still depreciates, albeit to a lesser extent than in the presence of capital controls. Thus, when capital controls are weak or nonexistent, the trade liberalisation is seen to attract increased inflows on the capital account and hence to mitigate the real depreciation and associated GDP price deflation that are its inevitable consequences.

In the third column of Table 14.7 the target of monetary policy is the GDP price, so that the nominal exchange rate is allowed to depreciate. This removes the deflation that must accompany a fixed exchange rate and hence reduces the rise in the production real wage due to the reforms. The GDP gain is therefore almost doubled and now only the processed food sector contracts in the short run. Interestingly, the additional investment and greater employment generated with the policy regimes of columns 2 and 3 ensure that real land rents actually rise in the short run.

Finally, the three right-hand columns of Table 14.7 indicate the short-run effects of the WTO accession reforms under the same three Chinese policy regimes but with the more optimistic ancillary effects of those reforms (Table 14.4) included. There are two key differences. First, investors are motivated by the effects of increased productivity in response to the reforms in the long run and, second, services reforms see a short-run increment to the capital stocks in the financial and communications sectors. These changes cause substantial rises in investment and, together, they cause larger net inflows on the capital account, boost the construction sector and reduce the cost of service inputs to other sectors. Overall expansions are therefore consistently larger in these cases, as is the demand for the sectoral relocation of workers. These are due, in part, to rises in overall employment which occur because of sticky nominal wages. The upward movement in nominal wages is slower than that in labour productivity, expanding aggregate labour demand by up to two per cent.

\section{Short-run sectoral impacts}

The key determinants of the sectoral mix of changes in the economy are the tariff reductions themselves, which reduce product prices in affected sectors, and the size of the resulting short-run real depreciation, which reduces non-traded (largely 
services) prices relative to traded goods prices. When capital controls are tight, the real depreciation is comparatively large. Traded sectors, such as light manufacturing, are advantaged, while non-traded services sectors, such as construction and dwellings, are disadvantaged. When capital controls are ineffective, manufacturing gains are smaller and the non-traded services sectors gain. Processed food suffers because of the decline in its protection, and other agricultural industries contract as that sector demands fewer local inputs. When the macroeconomic policy regime is expansionary, however, only the processed food sector contracts. If the optimistic ancillary effects are included the decline in the processed food sector becomes trivially small, ensuring gains to the agricultural sector as a whole. This result is quite important since, sensing losses due to reduced protection, the farm sector opposes the reforms. Yet if the reforms were embraced along with expansionary macroeconomic policy, the farm sector would be a net gainer, at least in the short run.

\section{Worker relocation demand in the short run}

The sectors defined for the purpose of our simulations (Table 14.2) are here aggregated for ease of comparison with the classification of employment by China's National Bureau of Statistics. The result is the seven sectoral groupings in Table 14.8. Also listed are the maximum and average annual changes in employment by sector, drawn from official statistics since 1978. The detailed official record of annual changes in employment by sector is provided in the Appendix. Some of these changes are of extraordinary magnitude, especially the growth in service sector employment in 1984. We discount these as due to changes in measurement in that year. There have also, however, been some extraordinary employment growth periods since then, including the service employment expansions of 1993 and 1994. Of course, the services sectors were considerably smaller then than they are now, and so the numbers of workers relocated to achieve those employment growth numbers were smaller than would now be required. Even so, these statistics suggest that China's capacity for the rapid sectoral relocation of workers has been considerable.

In the same table we show the range of simulated short-run worker relocation demands associated with China's WTO accession reforms. In interpreting these, it must be borne in mind that overall employment in China is endogenous in these simulations. From Table 14.7, depending on the macroeconomic policy settings, it either contracts by one-quarter of one per cent or expands by almost two per cent. 
Figure 14.8 Trade reform with capital controls

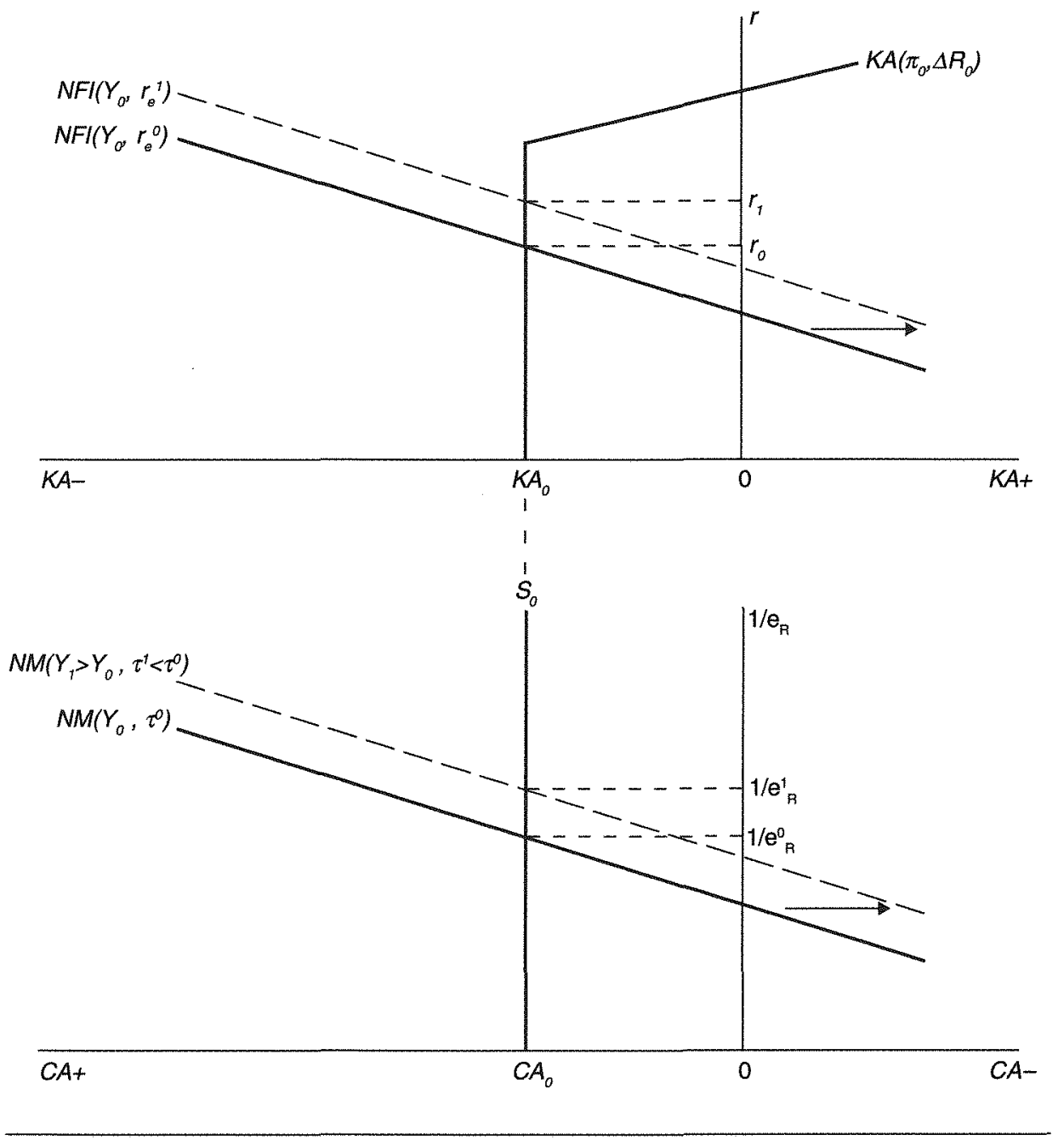


Figure 14.9 Trade reform without capital controls

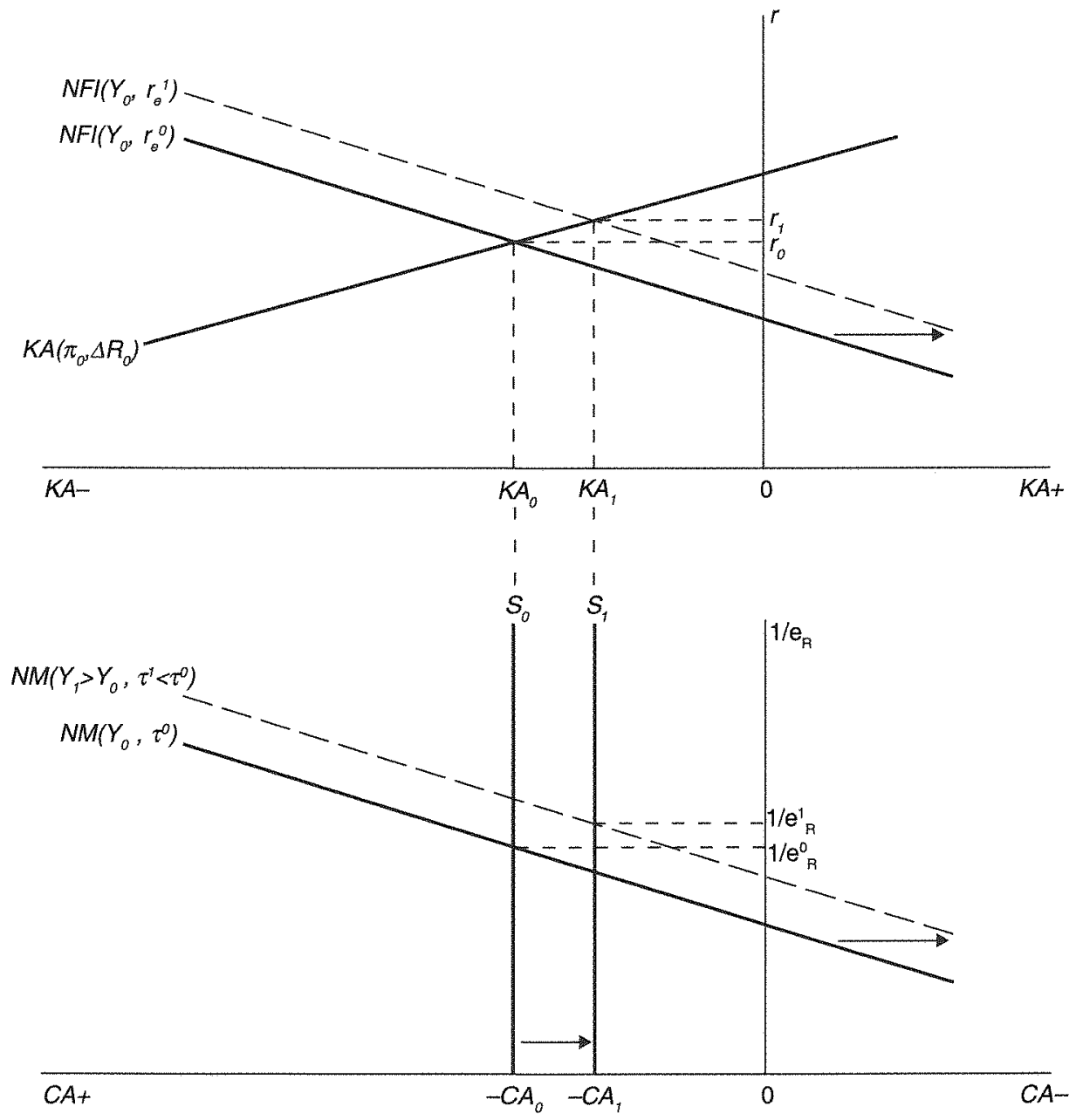




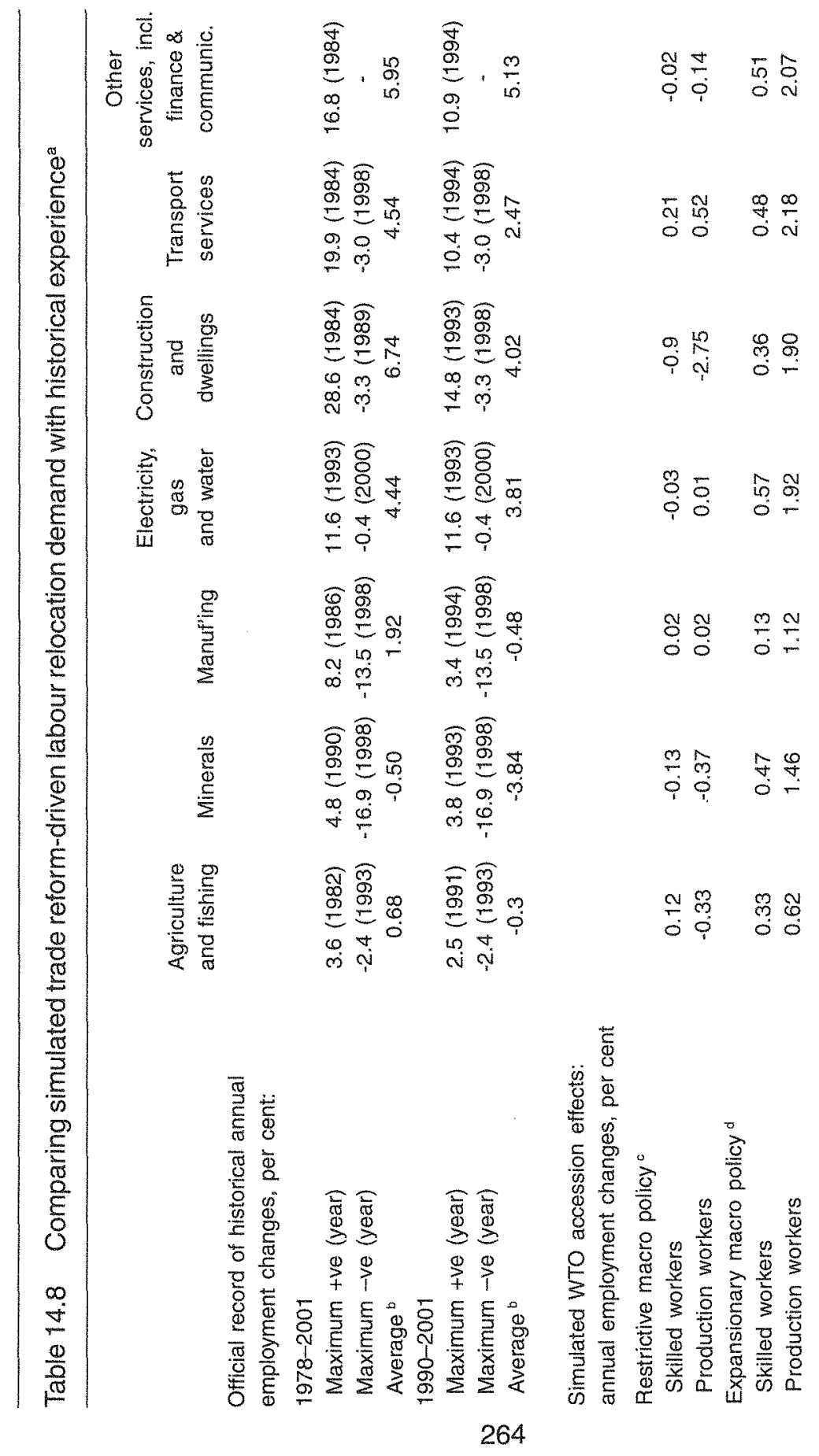




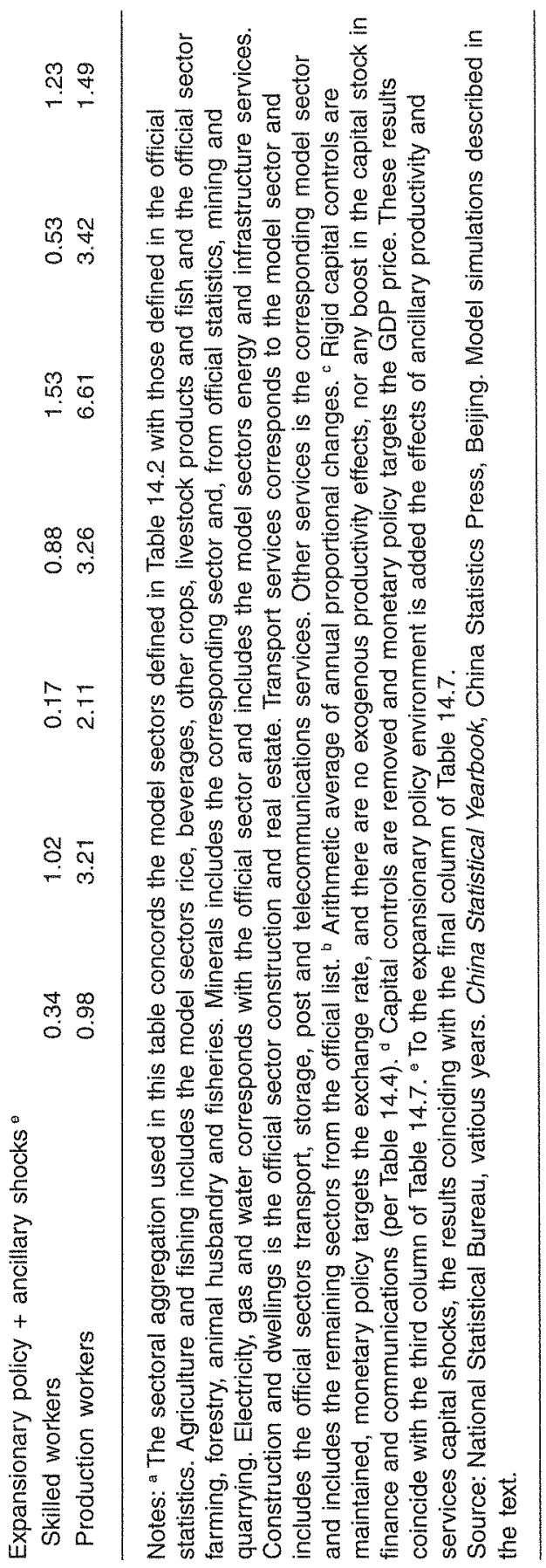


This opens the possibility that, at least in the short run, rural activity can expand at a sufficient pace to retain its workers. When we combine the most expansionary policy scenario with the ancillary effects of productivity and services reform (Table 14.4), the overall expansion permits employment in each sector to increase, as indicated in the final column of Table 14.8. Of course, there remains considerable redistribution of employment in these results, since the service sectors expand their labour use much more rapidly than does agriculture. Also, since we focus on the short run, we take no explicit account here of technical change in Chinese agriculture. In other countries at the same stage of development this change has been in labour saving, enabling the agricultural sector to shed workers more quickly (Anderson et al. 2003).

Our contention that the macroeconomic policy environment is important in determining the pace of worker relocation demand is borne out in these results. In all sectors there is a stark contrast between employment growth under tight capital controls and a fixed exchange rate regime on the one hand and an investment policy that renders the capital controls ineffective combined with a flexible exchange rate on the other. When the ancillary shocks to productivity and services capital are included, this gulf widens further. In the case of this most optimistic of scenarios, employment growth exceeds the average since 1990 in all but two sectors and the excess is largest in construction and dwellings and transport services. These strong worker relocation demands nonetheless fall short of the maxima achieved in a single year in all sectors, even since 1990.

Yet the WTO accession reforms are but a small part of the pantheon of China's overall reform program, the bulk of which is growth-enhancing. Not only do we exclude the trend of technology and associated organisational changes, as mentioned previously, but we take no direct account of the ongoing financial sector reforms and the continuing transformation of urban activity from the public to the private sector. Even in the case of China's WTO accession, we ignore commitments by China's trading partners to reduce protection against her labour-intensive exports. These changes will improve China's terms of trade and further stimulate its growth. Considering such omissions, worker relocation demand in a more expansionary policy environment could well approach, or even exceed, the high rates of change observed in the early 1990 s.

Finally, our simulations rest on the assumption that production and skilled workers in one sector are perfectly transformable into corresponding workers in other sectors. 
Because some workers have narrowly sector-specific education and training and because sectoral relocation attaches high transaction costs, particularly for rural families, the actual transformability of production workers will remain imperfect (Sicular and Zhao 2002). Our results therefore place upper bounds on the overall economic performance results from the WTO accession reforms and, more importantly for our purpose, upper bounds on worker relocation demands in the short run.

\section{CONCLUSION}

Our chronicle of changes in economic performance, income distribution and internal migration in China suggests a recent slowing of employment growth in the modern sector and the 'bottling up' of labour in rural activities, widening the income gap between urban and rural workers. This has happened in spite of what our review suggests is a considerable relaxation of the worker registration, or hukou, system which has constrained internal migration in the past.

To examine the hypothesis that the slowdown in overall growth, and the pace of worker relocation in particular, is due at least in part to a restrictive macroeconomic policy regime, we adapt a comparative static multi-product, multi-region macroeconomic model. We use the model to compare the economic effects of a key element of China's current economic reform program, namely its commitments associated with its accession to the WTO, under a variety of alternative macroeconomic policy regimes. These range from very restrictive capital controls combined with a fixed exchange rate to a regime with no capital controls (or the equivalent in FDI flexibility) and a flexible exchange rate. The results suggest these regimes make a difference of at least one per cent per year in overall GDP growth and at least two per cent per year in employment growth in the economy's modern sector. They therefore support our hypothesis, at least to the extent that the macroeconomic policy regime has contributed to a slowdown in the pace of expansion and worker relocation. Indeed, with an expansionary macroeconomic policy and optimistic assumptions about productivity effects associated with the WTO accession reforms and intersectoral worker transformability, simulated worker relocation demands from these reforms alone could exceed the average of China's recent experience.

While we are confident about our conclusion that China's macroeconomic policy regime has reduced economic performance relative to its theoretical potential, it 
does not follow that we advocate the immediate elimination of capital controls and the adoption of a floating exchange rate. The latter has been advocated recently by government representatives in Japan and the United States, including such significant players as the Chairman of the United States Federal Reserve. ${ }^{30} \mathrm{We}$ are more inclined to caution on the issue of the exchange rate, recognising that a float would be premature considering China's underdeveloped financial sector, its partially reformed banking industry and its still-vulnerable state-owned enterprises. ${ }^{31}$ The fact that more flexibility would enhance China's growth should be taken as indicating the need for acceleration of the financial sector reforms that are required before a floating rate regime can be implemented. ${ }^{32}$

\section{ACKNOWLEDGMENTS}

Funding for the research described comes, in part, from Australian Research Council Large Grant No. A201 and in part from ACIAR Project No.ADP/1998/128. Comments from Yongzheng Yang and assistance from Lucy Rees are appreciated.

\section{NOTES}

1 The contractionary effects of deflation do not end there. See Bordo and Redish (2003).

2 See Hertel (1997) for the original specification.

3 lanchovichina and Martin $(2001,2002)$ also examine the effects of WTO accession on labour relocation demand, and they offer an explicit analysis of the HRS. Their analysis, however, is strictly long run and ignores the short-run contractionary effects of macroeconomic policy emphasised here.

4 See Banister and Taylor (1989); Chai and Chai (1997); Hui (1989); Seeborg et al. (2000); and Multinational Monitor.

5 See Banister and Taylor (1989); Hul (1989); Seeborg, Jin and Zhu (2000).

6 See Banister and Taylor (1989); Hong Kong Liaison Office (IHLO). China's unemployment statistics measure only the urban unemployed.

7 Interestingly, just prior to the crisis (1995-96), the disparity actually narrowed. A grain shortage in 1994 had allowed a rise in prices for agricultural products relative to manufactures and hence a temporary improvement in the rural terms of trade. The effects of this on rural incomes were then bolstered by a return to good weather in 1995-96.

8 In 1984, it was estimated that about 40 per cent of workers in the countryside were redundant (Chai and Chai 1997). 
9 These restrictions tended to leave marginal urban residents underqualified for their jobs and migrants from rural areas overqualified. Meng and Zhang (2001) estimate these rates of under and over-qualification at 22 per cent for urban residents and 6 per cent for migrants from rural areas.

to Often quoted is the real effective exchange rate, which is a weighted average of bilateral real rates: $e_{i}^{R}=\sum_{j} E_{i j}\left(\frac{P_{i}^{Y}}{P_{j}^{Y}}\right)\left(\frac{X_{i j}+M_{i j}}{X_{i}+M_{i}}\right)$, where $X_{i}$ and $M_{i}$ are region $i s$ total values of exports and imports, respectively.

11 The analysis by Yang and Tyers $(2000,2001)$ suggests that the magnitudes of China's crisis period deflation might be understated by official statistics.

12 A detailed description of the original model is provided by Hertel (1997).

${ }_{13} T$, includes revenue from taxes on production, consumption, factor use and trade, all of which are accounted for in the original GTAP model and database.

${ }^{14}$ Private saving is derived as the difference between disposable income $(Y-T)$ and consumption expenditure, where real consumption is determined in a Keynesian reduced form equation that takes the form: $C=\gamma r^{\delta}[Y-T]^{\mu}$, where $r$ is the real interest rate.

15 Note that there is no allowance for interregional capital ownership in the starting equilibrium. At the outset, therefore, there are no factor service flows and the current account is the same as the balance of trade.

${ }^{16}$ By which it is meant that households can direct their savings to any region in the world without impediment. Installed physical capital, however, remains immobile even between sectors.

${ }^{\pi} r_{j}^{\theta}$ is the expected rental rate on physical capital (which, when physical capital is sector-specific, varies across sectors and thus is averaged), adjusted for depreciation and divided by the price of capital goods to yield a unitless net rate of return.

${ }^{18}$ Before adding to the global pool, savings in each region is deflated using the regional capital goods price index and then converted into US dollars at the initial exchange rate. The global investment allocation process is then made in real volume terms.

19 This investment relation is similar to Tobin's $Q$ in the sense that the numerator depends on expected future returns and the denominator indicates the current cost of capital replacement.

20 Since the initial database (GTAP Version 5) incorporates no 'net income' or factor service component in its current account, the initial equilibria must do likewise. This implies the assumption that, although there are no interregional bond holdings initially, the shocks implemented cause interregional exchanges of bonds and hence a non-zero net income flow in future current accounts not represented. 
21 More precisely, since for the US $E=1$, there is one less (usually endogenous) variable. Where nominal exchange rates are to be endogenous and nominal money supplies exogenous, one additional variable must be made endogenous. This could, for example, be balanced by making one price level exogenous, such as by having US monetary policy target the change in the US $C P I, P^{C}$.

22 The scope of monetary policy includes alterations in the rate at which official foreign reserves are accumulated. When there are no capital controls, however, the perfect capital mobility assumption implies that changes in reserves have no effect on net capital account flows. Where they are important is in the case where capital controls are effective. Because the manipulation of reserves offers only a short-term approach to exchange rate management that is only available if reserves are sufficient in the first place, $D R$ is held exogenous throughout the analysis in this chapter.

${ }^{2}$ Detailed descriptions of the GTAP database's content and sources as they relate to China are available in Gehlhar (2002), which describes the integration of the data for Hong Kong with that of the mainland and discusses the entrepot nature of some of Hong Kong's trade, Lin et al. (2002) for Taiwan and Wang et al. (2002) for the mainland.

${ }^{24}$ See Liu et al. (1998) for the method adopted.

$\approx$ For further discussion of the role and representation of skill-capital complementarity, see Tyers and Yang (2000).

2s Consequently, the rates in Table 14.3 tend to reflect the proportional changes in powers of tariffs implied by lanchovichina and Martin (2001) and the magnitudes as detailed in the protocol.

27 To the extent that some of the tariff reductions may in fact be phased in over several years, our analysis will tend to overstate the economic impacts in the short run.

$\approx$ The net factor income component of the current account is zero at the outset because that is the assumption embodied in the construction of the original database.

$\approx$ To see these at least partially offsetting gains in allocative efficiency it is necessary to use a multi-commodity general equilibrium framework such as that used in this chapter.

o Interestingly, this pressure has tended to be for a revaluation of the RMB, which would benefit both Japan and the US in the short run. The shocks we examine, however, yield real depreciations. Were these shocks dominant, we believe the fundamentals would be more likely to support a devaluation of the RMB. A revaluation would be justified only in the event of Chinese investment demand taking on 'bubble' characteristics, capital controls notwithstanding.

It See the discussion on this point by Edwards (2003).

32 See both Roberts and Tyers (2003) and Edwards and Levy-Yeyati (2003). 


\section{REFERENCES}

Anderson, K., Huang, J. and lanchovichina, E., 2002. Long-run Impact of China's WTO Accession on Farm-Non-farm Income Inequality and Rural Poverty, Paper presented at the World Bank Conference on China's WTO Accession, Policy Reform and Poverty Alleviation, Beijing, 28-29 June 2002.

Banister, J. and Taylor, J.R., 1989. 'China: surplus labour and migration', Asia-Pacific Population Journal, 4(4):3-20.

Bordo, M.D. and Redish, A., 2003. Is Deflation Depressing? Evidence from the classical gold standard, NBER Working Paper W9520, National Bureau of Economic Research, Cambridge, Massachusetts.

Chai, J.C.H. and Chai, B.K., 1997. 'China's floating population and implications', International Journal of Social Economics, 24(7-8-9):1038-51.

Chan, K.W., 2000. 'Internal migration in China: trends, determinants and scenarios', in China's Urbanization Strategy: opportunities, issues and policy options, World Bank and PRC State Development Planning Commission, Washington, DC and Beijing:56-63.

Chan, K.W. and Zhang, L., 1999. 'The Hukou system and the rural-urban migration in China: processes and changes', The China Quarterly, 160:818-55.

Chand, S., 1999. 'Trade liberalisation and productivity growth: time-series evidence from Australian manufacturing', The Economic Record, 75(228):28-36.

Chand, S., McCalman, P. and Gretton, P., 1998. 'Trade liberalisation and Manufacturing Industry Productivity Growth', in Productivity Commission and ANU Australian National University (eds), Microeconomic Reform and Productivity Growth, Ausinfo, Canberra:239-81.

Dee, P. and Hanslow, K., 2000. Multilateral Liberalisation of Services Trade, Productivity Commission, Melbourne.

Dolven, B., 2003. 'Take our workers, please', Far Eastern Economic Review, 27 February:24-26.

Edwards, S. 2003. 'China should not rush to float its currency', Financial Times, 3 August.

- - and Levy-Yeyati, E., 2003. Flexible Exchange Rates as Shock Absorbers, NBER Working Paper W9867, NBER, Cambridge, Massachusetts.

Garnaut, R., 1999. China After the East Asian Crisis, Paper presented to China Update 1999, National Centre for Development Studies, The Australian National University, Canberra, November. 
Gehihar, M.J., 2002.'Hong Kong's re-exports', in B.V. Dimaranan and R.A. McDougall (eds), Global Trade, Assistance and Production: the GTAP 5 Data Base, Center for Global Trade Analysis, Purdue University, West Lafayette. Available online at www.gtap.agecon.purdue.edu/databases/v5/v5_doco.asp.

Hertel, T.W. (ed.), 1997. Global Trade Analysis Using the GTAP Model, Cambridge University Press, New York.

Hong Kong Liaison Office (IHLO), 2002. China \& the WTO, Update and Analysis, Hong Kong Liaison Office, May 2002. Available online at http://www.ihlo.org/ item3/item3h-3.htm [accessed 4 December 2002].

Hui, D., 1989. 'Rural labour force transition and patterns of urbanization in China'. Asia Pacific Population Journal, 4(3):41-51.

lanchovichina, E. and W. Martin, 2001. 'Trade liberalisation in China's accession to the WTO', Journal of Economic Integration 16(4):421-45.

- 2002. Evaluating Accession to WTO by China and Chinese Taipei, Paper presented at the Fifth Annual Conference on Global Economic Analysis, Taipei, 5-7 June. Revised 11 December 2002. 'Economic Impacts of China's Accession to the WTO:'

Immigration and Refugee Board, Canada, 2002. China: internal migration and the floating population, Immigration and Refugee Board, Ottawa. Available online at http://www.irb.gc.ca/en/Researchpub/research/publications/chn11_e.htm [accessed 9 December 2002].

Lee, JW. And Rhee, C., 1999. Social Impacts of the Asian Crisis: Policy Challenges and Lessons, UNDP Working Paper 33, United Nations Development Programme, New York.

Lin, H.C., Chung, L., and Liou, R.W., 2002. 'Taiwan', in B.V. Dimaranan and R.A. McDougall (eds), Global Trade, Assistance and Production: the GTAP 5 Data Base, Center for Global Trade Analysis, Purdue University, West Lafayette:Chapter 11. Available online at www.gtap.agecon.purdue.edu/databases/v5/v5_doco.asp. Liu, J.N., Van Leeuwen, T., Vo, T., Tyers, R., and Hertel, T.W., 1998. Disaggregating Labor Payments by Skill Level in GTAP, Technical Paper 11, Center for Global Trade Analysis, Purdue University, West Lafayette. Available online at http:// www.agecon.purdue.edu/gtap/techpapr/tp-11.htm.

Lozada, C., 2002. 'Globalization reduces inequality in China', The NBER Digest, March:1. 
Meng, X., 1998. Recent Development in China's Labour Market, Paper presented at China Update 1998, National Centre for Development Studies, The Australian National University, Canberra.

Meng, X. and Zhang, J., 2001. The two-tier labour market in urban China: occupational segregation and wage differentials between urban residents and rural migrants in Shanghai', Journal of Comparative Economics, 29(3)485-504.

Multinational Monitor, 2000. Sewing up the Chinese market-The effect of WTO Entry on the Chinese Rural Sector, Multinational Monitor, Avalable online at www.multinationalmonitor.org/mm2000/00may/weil.html [accessed 4 December 2002].

National Bureau of Statistics, various years. China Statistical Yearbook. China Statistics Press, Beijing.

Rees, L. and Tyers, R., 2002. Trade Reform in the Short Run: China's WTO Accession, Working Papers in Economics and Econometrics 423, The Australian National University.

Roberts, I. and Tyers, R., 2003. 'China's exchange rate policy: the case for greater flexibility', Asian Economic Journal, 17(2):157-86.

Seeborg, M.C., Jin, Z. and Zhu, Y., 2000. 'The new rural-urban labour mobility in China: Causes and implications', The Journal of Socio-Economics, 29(2000):3956.

Sicular, T. and Zhao, Y., 2002. Labor Mobility and China's Entry to the WTO, Paper presented at the conference on WTO Accession, Policy Reform and Poverty Reduction, Beijing, June 26-28.

Stoeckel, A., Tang, K.K., and McKibbin, W., 1999. The Gains from Trade Liberalisation with Endogenous Productivity and Risk Premium Effects, Technical Paper prepared for the seminar Reasons versus Emotion: Requirements for a Successful WTO Round, Seattle, 2 December.

Tyers, R. and Rees, L. 2002. Trade Reform and Macroeconomic Policy in Vietnam, Working Papers in Economics and Econometrics 419, The Australian National University. Also presented at the Fifth Annual Conference on Global Economic Analysis, Taipei, June.

Tyers, R. and Yang, Y., 2000. 'Capital-skill complementarity and wage outcomes following technical change in a global model', Oxford Review of Economic Policy, 16(3):23-41. 
- 2001. Short Run Global Effects of US 'New Economy' Shocks: the role of capital-skill complementarity, Paper presented at the Fourth Annual Conference on Global Economic Analysis, Purdue University, West Lafayette, 27-29 June. Available online at http://ecocomm.anu.edu.au/people/rod.tyers.

Verikios, G. and Zhang, X., 2001. The Economic Effects of Removing Barriers to Trade in Telecommunications and Financial Services, Paper presented the Fourth Annual Conference on Global Economic Analysis, Purdue University, West Lafayette, 27-29 June.

Wang, Z., Zhai, F., and Xu, D., 2002. 'China', in B.V.Dimaranan and R.A. McDougall (eds), Global Trade, Assistance and Production: the GTAP 5 Data Base, Center for Global Trade Analysis, Purdue University, West Lafayette:Chapter 11C. Available online at www.gtap.agecon.purdue.edu/databases/v5/v5_doco.asp.

Yang, Y., 1998. China in the Middle of the East Asian Crisis: export growth and the exchange rate, paper presented at China Update 1998, National Centre for Development Studies, The Australian National University, Canberra.

Yang, Y. and Tyers, R., 2000. China's Post-crisis Policy Dilemma: multi-sectoral comparative static macroeconomics, Working Papers in Economics and Econometrics 384, The Australian National University, Canberra. Revised edition available online at http://ecocomm.anu.edu.au/people/rod.tyers.

- 2001. 'The Asian crisis and economic change in China', Japanese Economic Review, 52(4):491-520.

Zhao, Y., 2000. 'Rural to urban labour migration in China: past and present', in L.A. West and Y. Zhao (eds), Rural Labour Flows in China, University of California Press, Berkeley:15-33. 


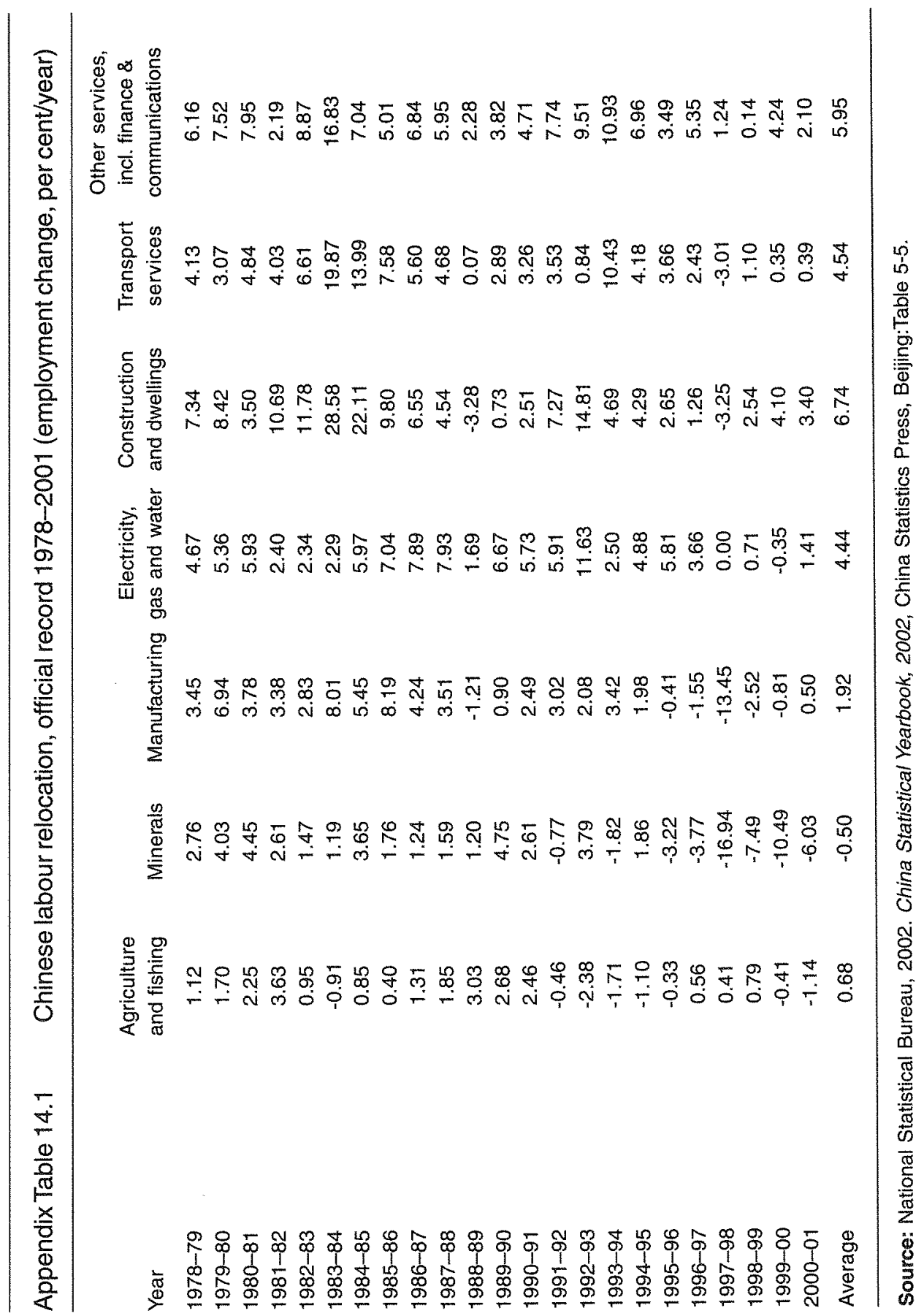

